BIJDRAGEN TOT DE KENNIS DER FAUNA VAN CURAÇAO.

Resultaten eener reis van Dr. C. J. VAN DER HORST in 1920.

\title{
THE MACRURAN, ANOMURAN AND STOMATOPOD CRUSTACEA
}

BY

\author{
WALDO L. SCHMITT, \\ United States National Museum.
}

(With seven text figures and one plate).

Though small in point of numbers this collection, secured by Dr. VAN DER HORST, has proven intensely interesting, and I am exceedingly indebted to him for his kindness in permitting me to report upon it. Though not all the species recorded by Dr. MARY J. Rathbun from Curaçao (in Rapport betreffende een voorloopig onderzoek naar den toestand van de Visscherij en de Industrie van Zeeproducten in de Kolonie Curaçao, uitgebracht door Prof. Dr. J. BoEkE, pt. 2, 1919 (1920)), forty one $(+1$ ?) species exclusive of Crangonids (Alpheids) of which there were eighteen $(+2$ ?) were collected. Eight are apparently undescribed forms. These are: Penaeopsis smithi, Synalpheus curaçaoensis, Hippolyte curaçaoensis, Periclimenes rathbunae, Petrolisthes vanderhorsti, Pisosoma curaçaoensis, Axianassa intermedia, and Gonodactylus oerstedii var. curaçaoensis.

No attempt has been made to give more than the most pertinent and recent references under the various species. The accompanying photographs have been generously donated by Mr. CLARENCE R. Shoemaker, of the United States National Museum, who was kind enough to take them for me; the retouching was done by Miss LuDwickA WIESER. The drawings, for the greater part, were made with the aid of the Edinger drawing apparatus.

\section{Family PENEIDE.}

\section{Peneus brasiliensis Latreille.}

Penaeus brasiliensis Latreille, Nouv. Dict. Hist. Nat., vol. 25, 1817, p. 156; Rathbun, Bull. U. S. Fish Comm., vol. 20 , pt. 2, 1900 (1901), p. 100; VerRill, Trans. Conn. Acad., vol. 26, 1922, p. 41, pl. 13, figs. 1-3, pl. 16, figs. 1, 2, 2a, pl. 17, fig. 10, d, e, f.

Peneus brasiliensis RATHBUN, Rapport betreftende een voorloopig onderzoek naar den toestana van de Visscherij en de Industrie van Zeeproducten in de Kolonie Curaçao, uitgebracht door Prof. J. BoEkE, pt. 2, 1920, p. 318, [3].

Spanish Water: in mud, 19. V.20, 2 juvenile.

Caracas Bay: 19. IV.20, 1 \%.

Remarks. - The female from Caracas Bay measures $129 \mathrm{~mm}$. in length, carapace and rostrum $45.5 \mathrm{~mm}$., and the rostrum $18 \mathrm{~mm}$. long.

\section{Penaeopsis goodei (Smith).}

Parapenaeus goodei Smith, Proc. U. S. Nat. Mus., vol. 8, 1885, p. 176; VerRILl, Trans. Conn. Acad., vol. 26,1922, p. 44, pl. 16, fig. 3; RATHBUN, Rapport betreffende een voorloopig onderzoek naar den toestand van de Visscherij en de Industrie van Zeeproducten in de Kolonie Curaçao, uitgebracht door Prof. J. BOEKE, pt. 2, 1920, p. 320 [4]. (nec P. goodei Bouvier).

Spanish Water: 3. IV. 20, 1 ㅇ. 
Penaeopsis smithi new species.

Type locality. - Caracas Bay: 10. IV.20, $10^{7} 1$ ㅇ.

Additional specimens. - Caracas Bay: 19. IV. 20, 2 immature; sieved out of sand, 13. V.20, $3 \sigma^{\circ} 2$, 2 juvenile.

Dimensions. - Of the figured $q$ : length of rostrum $7 \mathrm{~mm}$., carapace and rostrum together $16.5 \mathrm{~mm}$., abdomen to tip of telson about $27 \mathrm{~mm}$. long.

Description. - An apparently undescribed species of Penaeopsis, much of the appearance of Penaeopsis goodei Smith (Proc. U. S. Nat. Mus., vol. 8, 1885, p. 176).

The rostrum is a little more slender though a little shorter than in most specimens of $P$. goodei, reaching at least to the end of the second article of the antennular peduncle and usually beyond to about the middle of the last segment of the peduncle; in $P$. goodei the rostrum is generally longer, often reaching to the end of the antennular peduncle. The figure given by VerRILl (Trans. Conn. Acad., vol. 26, 1922, pl. 16, fig. 3), said to be of the type which I have not seen, has however, the rostrum much shorter, shorter than any in a considerable series examined, not even reaching the distal margin of the second segment. The rostrum is armed above with 9 or 10 teeth of which the first is on the carapace and as far removed from the second as the distance between the second and a point between the fourth and fifth teeth; the last tooth in the case of specimens furnished with 10 teeth is often but a tiny denticle tucked in almost under the penultimate tooth, which is about as far, a little more or less, from the tip of the rostrum as it is from the antepenultimate tooth.

The outer spine, or scale of the antennular peduncle falls short of, or scarcely reaches the middle of the cornea, while in $P$. goodei, it extends forward two thirds the length of the cornea, and I have seen one case in which it attained as much as three fourths the length of the cornea; the antennal scale is a little longer than the antennular peduncle.

The hairs forming the pubescence on the branchial region appear to be simple, while those of $P$. goodei as described by SMITH are plumose. There are exopodites on all of the legs, and epipodites on all but the last two pairs; the last pair of legs is, as usual in this genus without gills; the penultimate pair has both arthrobranch and pleurobranch, the next several preceding pairs of legs have the customary two arthrobranchs and one pleurobranch.

But it is by means of the thelycum that that species is best distinguished from related species. The anterior plate is inverted $U$-shaped, topped by a short spine on the outer curve of the $U$;

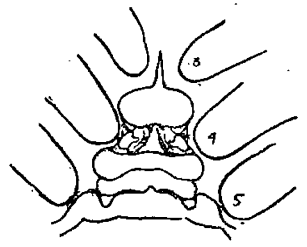

$\alpha$

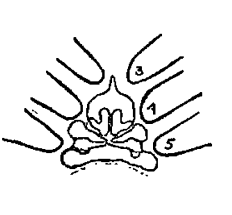

b

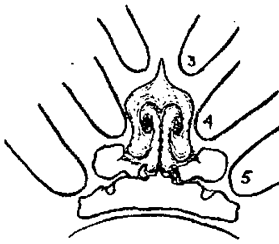

$c$

Fig. 1. - $a$. Thelycum of Penaeopsis goodei Smith. $b$. Thelvcum of Penaeopsis smithi, new species, immature. $c$. Th
of Penaeopsis smithi, new species, aduit. enclosed in it are two longitudinal, curved elements, one either side but close to the median line curving outward to enclose between either of them and the adjacent limb of the $U$ an elongate, elliptical depression; the limbs of the $U$ which curve inward and continue to form the curved elements above, rest upon the transverse plate between the bases of the fourth pair of legs; in the middle this plate is so narrowed down as to have become virtually obliterated behind the posterior extremities of the median curved elements of the thelycum; in smaller, evidently younger specimens the anteriorly directed curve of the $U$ is wider, forming a more or less evident plate about as wide as the spine which tops it, the curved elements within the $U$ partake more of the nature of platelets, though still more elongate in a longitudinal direction than transversely. In $P$. goodei, the anterior plate of the thelycum is transversely oblong with broadly rounded ends; before, it carries on the median line a long slender spine; behind, two small, peculiar, more or less rounded platelets are embedded near each postero-lateral angle; they are wider in an obliquely transverse direction than long, and are placed well to either side of the median line; the transverse plate lying posterior to these platelets is quite wide on the median line of the sternum, which in both species carries a pair of long slender spines between the bases of the second pair of legs; these spines appear to be relatively more slender in our species than in $P$. goodei. The petasma is asymmetrical and the ventral-most element is a deeply cleft, bifurcate, membranous flap, folded over from the right side. 
The abdomen is not carinated in advance of the fourth somite, though it and the fifth and sixth show as distinct a carina as $P$. goodei has extending forward to include the dorsum of the third, and in part often the second somite as well. The absence of carination on the third somite furnishes a ready means of separating our species from $P$. goodei.

Remarks. - At first it seemed possible that we had come upon the $P$. pubescens described by Stimpson (Ann. Lyc. Nat. Hist., N. Y., vol. 10, 1871, p. 133), but from this species too, the noncarinated third abdominal somite sharply setts off our species. STIMPSON speaks of the abdomen of his species as "carinated from the second somite backward".

The P. goodei of Bouvier (Bull. Mus. océanogr. Monaco, No. 119, 1908, p. 7, and Mem. Mus. Comp. Zoöl., vol. 27, 1909, p. 226, pl. 4, figs. 6-10, text fig. 55) seems to be a species other than the one described by SMITH; not only does the thelycum have a different shape, but the hairs on the lateral branchial region at least, are simple, and the outer spine, or scale of the antennules is shorter; the armature too, of the telson is different. In $P$. goodei Smith, barring variations of which there are many, the posterior, movable spines of the telson reach at least as far as and often beyond the fixed lateral, subterminal pair, while those of the second, movable pair, reach a greater or less distance past the bases of the second pair, but by no means to their middle. The telson of $P$. goodei is much like that figured by BOUvier (loc. cit., text fig. 55), except that the spines of the second, movable pair are longer, and usually also those of the posterior pair, as well. VERRILL (op. cit.; p. 45) has also noticed that BouvieR's $P$. goodei differs from the form originally described by SMITH, for he says, it seems to him to be a "distinct variety".

In many respects BouvieR's species resembles the one here described, but again the thelycum is different, and in our species the terminal point of the telson is very much less slender, and the lateral view of the specimen figured ( $o p$.
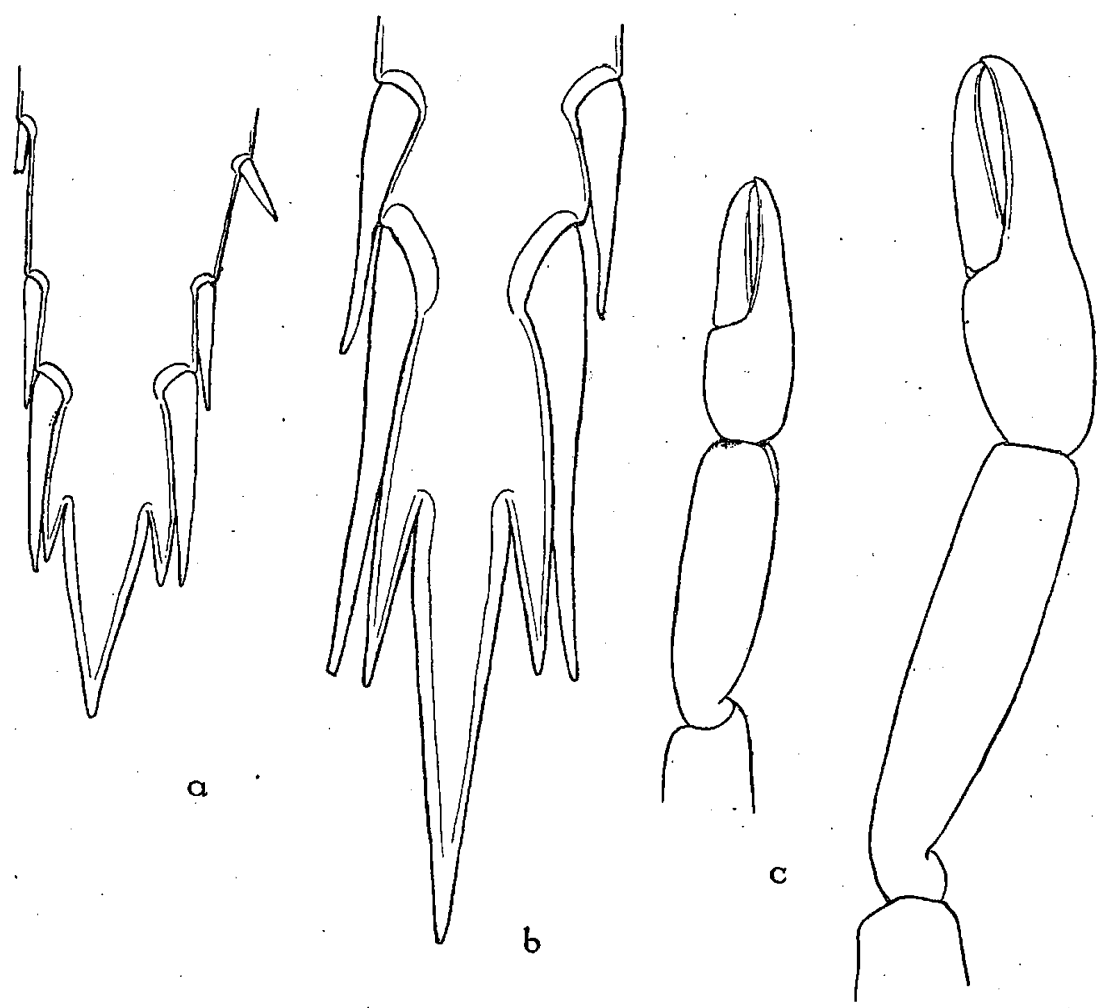

d

Fig. 2. - $a$. End of telson of Penaeopsis smithi, new species. $b$. End of telson of Penceopsis goodei Smith. c. Hand and carpus of first leg of Penceopsis smithi, new species, in outline. $d$. Hand and carpus of first leg of Penaeopsis goodei, Smith, in outline.

cit., pl. 4, fig. 6) indicates the presence of a carina on all the abdominal somites, except the first, beginning a little before the middle of the second somite. From the comparisons given (op. cit., p. 227) Bouvier's $P$. pubescens seems near the $P$. goodei of SMITH, but for the striking armature of the telson of which Bouvier says, "the posterior movable spines attain almost the tip of the telson, and those of the second pair, the apices of the lateral spines". In fact there seems no choice left but to revive BouvieR's original name, vestitus, for this species, and it should be noted moreover that we have no assurance that the telson figured by him (op. cit., text fig. 55) belongs to the same species, or still another, as he first supposed, $P$. rathbuni.

The more readily tabulated characters of the several species herein discussed are presented below, those of BouvieR's two species being taken from Bull. Mus. Comp. Zoöl., vol. 27, 1909, p. 227 : 


\begin{tabular}{|c|c|c|c|c|}
\hline Penaeopsis & smithi, new species. & goodei Smith. & goodei Bouvier. & pubescens Bouvier. \\
\hline $\begin{array}{l}\text { Hairs forming pube- } \\
\text { scence on branchial } \\
\text { region. }\end{array}$ & Simple & $\begin{array}{c}\text { Plumose } \\
.\end{array}$ & Simple & Plumose \\
\hline Rostrum & $\begin{array}{l}\text { To about middle of } \\
\text { last segment of anten- } \\
\text { nular peduncle, some- } \\
\text { times a little shorter. }\end{array}$ & $\begin{array}{l}\text { Often almost as long } \\
\text { as antennular pedun- } \\
\text { cle. }\end{array}$ & $\begin{array}{l}\text { Reaching at least to } \\
\text { middle of second seg- } \\
\text { ment of antennular pe- } \\
\text { duncle. }\end{array}$ & $\begin{array}{l}\text { ? Longer than in } P \text {. } \\
\text { goodei Bouvier. }\end{array}$ \\
\hline Antennular scale & $\begin{array}{l}\text { Not passing middle } \\
\text { of cornea. }\end{array}$ & $\begin{array}{l}\text { Passing middle of } \\
\text { cornea, to } 2 / 3 \text {, more } \\
\text { rarely } 3 / 4 \text { of cornea. }\end{array}$ & $\begin{array}{l}\text { Not passing middle } \\
\text { of cornea. }\end{array}$ & $\begin{array}{l}\text { Passing middle of } \\
\text { cornea. }\end{array}$ \\
\hline Fingers of first legs & Longer than palm. & $\begin{array}{l}\text { As long as or long- } \\
\text { er than palm. }\end{array}$ & $\begin{array}{l}\text { Almost as long as } \\
\text { palm. }\end{array}$ & Longer than palm. \\
\hline Abdomen carinated & $\begin{array}{l}\text { From fourth somite } \\
\text { backwards. }\end{array}$ & $\begin{array}{l}\text { From third somite } \\
\text { backward, in part on } \\
\text { second. }\end{array}$ & $\begin{array}{l}\text { From last half of } \\
\text { second somite back- } \\
\text { ward. }\end{array}$ & $\begin{array}{l}\text { ? As in } P \text {. goodei } \\
\text { Bouvier. }\end{array}$ \\
\hline $\begin{array}{l}\text { Lateral immovable } \\
\text { spines of telson. - }\end{array}$ & $\begin{array}{l}\text { Not reaching middle } \\
\text { of terminal point. }\end{array}$ & $\begin{array}{l}\text { Not reaching middle } \\
\text { of terminal point. }\end{array}$ & $\begin{array}{l}\text { Attaining at least the } \\
\text { middle of the terminal } \\
\text { point. }\end{array}$ & $\begin{array}{l}\text { Much shorter than } \\
\text { in } P \text {. goodei Bouvier, } \\
\text { not reaching middle of } \\
\text { terminal point. }\end{array}$ \\
\hline $\begin{array}{l}\text { Posterior movable } \\
\text { spines. }\end{array}$ & $\begin{array}{l}\text { Reaching about as } \\
\text { far as lateral spines. }\end{array}$ & $\begin{array}{l}\text { At least reaching as } \\
\text { far as lateral spines. } \\
\end{array}$ & $\begin{array}{l}\text { Not surpassing the } \\
\text { lateral spines. }\end{array}$ & $\begin{array}{l}\text { Reach tip of telson, } \\
\text { "free extremity of term- } \\
\text { inal point." }\end{array}$ \\
\hline $\begin{array}{l}\text { Second pair of mov- } \\
\text { able spines. }\end{array}$ & $\begin{array}{l}\text { Surpassing bases of } \\
\text { posterior movable } \\
\text { spines. }\end{array}$ & $\begin{array}{l}\text { Surpassing bases of } \\
\text { posterior movable } \\
\text { spines. }\end{array}$ & $\begin{array}{l}\text { Not surpassing bases } \\
\text { of posterior movable } \\
\text { spines. }\end{array}$ & $\begin{array}{l}\text { Almost reach apices } \\
\text { of lateral spines. }\end{array}$ \\
\hline $\begin{array}{l}\text { Terminal point of } \\
\text { telson }\end{array}$ & $\begin{array}{l}\text { Short, about } 2^{2} / 3 \text { times } \\
\text { as long as greatest } \\
\text { width. }\end{array}$ & $\begin{array}{l}\text { Long and slender, } \\
\text { nearly } 5 \text { times as long } \\
\text { as greatest width. }\end{array}$ & $\begin{array}{l}\text { Very long and slend- } \\
\text { er, about } 6^{1} / 2 \text { times as } \\
\text { long as greatest width. }\end{array}$ & $?$ \\
\hline
\end{tabular}

\section{Family CRANGONIDE.}

Crangon candei (Guérin).

Alpheus candei Guérin, in La Sagra's Hist. Cuba, pt. 2, vol. 7, 1857, p. 19, pl. 2, fig. 9; Coutière, Proc U. S. Nat. Mus., vol. 37,1910 , p. 486 , text fig. 1.

Alpheus dentipes Rathbun, Bull. U. S. Fish Comm., vol. 20, pt. 2, 1900 (1901), p. 105.

Alpheus or Crangon candei VerRill, Trans. Conn., vol. 26, 1922, p. 68, text fig. 5b, pl. 19, figs. 3a-d, pl. 20, fig. 1, pl. 21, figs. 6, 6a, pl. 24, figs. 2, 4, pl. 25, figs. 7, 8, pl. 29, figs. la-t.

Caracas Bay: under stone at the shore, 3.V.20, 1 specimen; from Porites furcata, 5. V.20, 2 specimens.

\section{Crangon malleator (Dana).}

Alpheus malleator DANA, Crust. U. S. Expl. Exped., vol. 1, 1852, p. 557, atlas, 1855, p1. 31, fig. 9a-h. Alpheus malleator var. edentatus ZIMMER, Zool. Jahrb., suppl. 11, hft. 3, 1913, p. 387, text figs. G-M.

Caracas Bay: from Maeandra, 7. IV. 20, 1 specimen; from a Gorgonian, 10. IV. 20, 1 specimen; from a Gorgonian, 10. IV. 20, 1 specimen.

Spanish Bay: between stones in the surf, 11. V.20, 4 specimens.

Remarks.- The small specimen from Maeandra from Caracas Bay, 7. IV. 20, represents the variety edentatus Zimmer, the small teeth or points between these teeth on the orbital hoods and the rostrum are wanting. There is possibly the merest suggestion of them in a very slight irregularity in the frontal margin where they normally occur. This specimen is about $10 \mathrm{~mm}$. long, the length given by ZIMMER for the type of his variety. Can the development of these secondary projections be possibly an adult or mature character? Two of the four specimens from Spanish Bay are $29 \mathrm{~mm}$. long, 
a third is $35 \mathrm{~mm}$. long, the fourth but 15 , the projections are clearly marked in each of these as well as the other, $21 \mathrm{~mm}$. long specimen from Caracas Bay.

\section{Crangon formosus (Gibbes).}

Alpheus formosus GibBes, Proc. Amer. Assoc. Adv. Sc., vol. 3, 1850, p. 196 [32]; RathBun, Bull. U. S. Fish Comm., vol. 20, pt. 2, 1900 (1901), p. 106.

Alpheus panamensis ZimMER, Zool. Jahrb., suppl. 11, hft. 3, 1913, p. 391, text figs. N-V.

Alpheus formosus or Crangon formosus VeRRILl, Trans. Conn. Acad., vol. 26, 1922, p. 84, text fig. $5 \mathrm{~d}$, ? text

fig. 6 a, pl. 19 , figs. 1,2 , pl. 20 , fig. 3 , pl. 23, fig. 5, a, b, pl. 20, fig. 4, a-u, pl. 25, figs. 6, 6 a.

Spanish. Water: from Porites furcata, 13. IV. 20, 2 specimens.

Caracas Bay: under stone at the shore, 3.V.20, 1 specimen; from Porites astreoides, 5. V. 20, 1 specimen.

\section{Crangon cristulifrons (Rathbun).}

Alpheus obeso-manus Pocock, Journ. Linn. Soc. London, Zool., vol. 20, 1890, p. 520 (nec Dana).

Alpheus cristulifrons Rathbun, Proc. Wash. Acad. Sci., vol. 2, 1900, p. 152; Bull. U. S. Fish Comm., vol. 20, pt. 2, 1900 (1901), p. 106.

Alpheus cylindricus ZIMMER, Zool. Jahrb., suppl. 11, hft. 3, 1913, p. 394.

Caracas Bay: 19. IV.20, 13 specimens; from Porites furcata, 19. IV. 20, 1 specimen; 5. V. 20, 6 specimens; from sponge, 10. V.20, 2 specimens; from Porites furcata, 13. V. 20, 25 specimens.

Spanish Water: from Porites furcata, 5. V. 20, 2 specimens.

Plantation Hato: fresh water, 28. IV.20, 1 specimen.

\section{Crangon floridanus (Kingsley).}

Alpheus floridanus Kingslex, Bull. U.S. Geol. Survey, vol. 4, 1878, p. 193; RAThBun, Bull. U. S. Fish Comm. vol. 20, pt. 2, 1900 (1901). p. 107; ZIMMER, Zool. Jahrb., suppl. 11, hft. 3, 1913, p. 398, text figs. C'-J1'.

Caracas Bay: in a small pool, 26.IV.20, 1 specimen; 8. V.20, 2 specimens.

Spanish Water: 3. IV.20, 4 specimens; 26. IV.20, 1 specimen; with the sieve, 4. V.20, 1 specimen.

Spanish Port; with the sieve, 17. IV.20, 1 specimen.

\section{Crangon rostratipes (Pocock).}

Alpheus rostratipes Pocock, Journ. Linn. Soc. London, Zool., vol. 20, 1890, p. 522; RATHBUN, Bull. U. S. Fish Comm., vol. 20, pt. 2, 1900 (1901), p. 108.

Caracas Bay: from Porites furcata, 5. V.20, 1 우 ovigerous.

\section{Crangon heterochaelis (Say).}

Alpheus heterochaelis SAY, Journ. Acad. Nat. Sci. Phila., vol.;1, 1818, p. 243; Rathbun, Bull. U.S. Fish Comm., vol. 20, pt. 2, 1900 (1901), p. 107 (pars); Coutière, Proc. U. S. Nat. Mus., vol. 37, 1910, p. 485 (under Alpheus armillatus H. M. Edw.).

Alpheus heterochaelis or Crangon heterochaelis VerRILl, Trans. Conn. Acad., vol. 26, . 1922, p. 76, pl. 22. figs. 1,2 and $4, \mathrm{a}-\mathrm{c}$, pl. 24, figs. 7, 7a, pl. 30, figs. 1, 1a, 1t, $2 \mathrm{a}-\mathrm{e}$, pl. 33, fig. 1, 2 .

Caracas Bay: 26.IV.20, 1 specimen; small pool between mangroves, 26. IV.20, 1 specimen; in a small pool, 26. IV. 20,4 specimens.

Spanish Water: 3.IV.20, 8 specimens; 26.IV.20, 1 q ovigerous; 19. V.20, 4 specimens.

Spanish Port: 10. IV. 20, 7 specimens; sieved out of the sand, 16. IV.20, 1 specimen, and 17. IV. 20, 3 specimens.

\section{Crangon armillatus (M. Edw.)}

Alpheus armillatus MiLNE Edwards, Hist. Nat. Crust., vol. 2, 1837, p. 354; ZIMmer, Zool. Jahrb., suppl. 11, hft. 3, 1913, p. 401, text figs. $\mathrm{K}^{1}-\mathrm{T}^{1}$.

Alpheus heterochaelis RAThBun, Bull. U. S. Fish Comm., vol. 20, pt. 2, 1900 (1901), p. 107 (pars).

Alpheus armillatus or Crangon armillatus VerRiLl, Trans. Conn. Acad., vol. 26, 1922, p. 73, text figs. 5a, $6 \mathrm{~b}$, pl. 20 , fig. 4 b, pl. 21 , figs. $4,4 \mathrm{a}$, pl. 23 , fig. 4 , pl. 26 , figs. $1-1 \mathrm{~d}$, pl. 27 , figs. $1-1 \mathrm{~s}$, and synonymy.

Spanish Water: 7. V.20, 1 우 ovig.; sieved from sand, 13. V.20, 1 specimen.

\section{Crangon bahamensis (Rankin).}

Alpheus hippothoë var. bahamensis Rankin, Ann. N. Y. Acad. Sci., vol. 11, N0 12, 1898, p. 247, pl. 30 , fig. 5. Alpheus hippothö̈ var. edamensis? ZIMMER, Zool. Jahrb., suppl. 11, hft. 3, 1913. p. 405, text figs. $\mathrm{U}^{1}-\mathrm{Z}^{1}$. Alpheus bahamensis. Verrill, Trans. Conn. Acad., vol. 26, 1922, p. 70, pl. 20, figs. 6, 6a, pl. 28, figs. 1, a-1, 2, 3-31.

Caracas Bay: 1. V.20, 1 specimen. 
Crangon species?

(Incomplete specimens not determined.)

Caracas Bay: 19.IV.20, 1 specimen; from Porites furcata, 23.IV.20, 1 specimen; from sponge, 10. V.20, 1 specimen.

Synalpheus hemphilli Coutière.

Synalpheus hemphilli CouTIĖRE, Proc. U. S. Nat. Mus.. vol. 36, 1909, p. 38, text fig. 20.

Caracas Bay: from sponge, 5. V.20, 2 specimens.

Synalpheus fritzmülleri Coutière.

Synalpheus fritzmüllleri CoutıĖRE, Proc. U. S. Nat. Mus., vol. 36, 1909, p. 35, text fig. 18; ZIMMER, Zool. Jahrb., suppl. 11, hft. 3, 1913, p. 382 .

Caracas Bay: from Maeandra, 7.IV.20, 4 specimens; under stone at the shore, 3.V. 20, 1 specimen; under stone, 18. V. 20, 1 specimen.

Spanish Bay: 11. V.20, 2 specimens.

West Punt: 14. V.20, 2 specimens.

? Synalpheus apioceros near desterroensis Coutière.

Synalpheus apioceros desterroensis CoutièRE, Proc. U. S. Nat. Mus., vol. 36, 1909, p. 31, text fig. 13.

West Punt: 14. V.20, 2 specimens.

Remarks. - Though surely belonging to the Paulsoni group, the frontal teeth of these specimens appear quite short, and the short, but slender rostrum does not exceed the lateral teeth. The large chela is spined above; the scaphocerite exceeds the antennular peduncle, the stylocerite reaches nearly to the second segment of the peduncle, thus exceeding the ventral spine of the basicerite, which does not quite reach the middle of that joint; superior spine of basicerite well developed.

Synalpheus townsendi scaphoceris Coutière.

Synalpheus townsendi scaphoceris Coutıère, Proc. U. S. Nat. Mus., vol. 37, 1910, p. 486, text fig. 2.

Spanish Water: from Porites furcata, 5. V.20, 2 specimens.

Remarks. - The rostrum is a little broader than in the type, being much more like the one figured for S. townsendi brevispinis from Lower California (Coutiere, Proc. U. S. Nat. Mus., vol. 36, 1907, text fig. 16, p. 33).

\section{Synalpheus curaçaoensis new species.}

Type-locality. - Spanish Bay: between stones in the surf, 11.IV.20, 14 specimens.

Additional specimen. - Caracas Bay: from Gorgonian, 10. IV.20, 1 specimen.

Dimensions. - Largest specimen, one ovigerous female, with rostral tip broken, carapace and rostrum about 5.8 , abdomen about 8.5 , and large chela $6.2 \mathrm{~mm}$. long; figured specimen, ovigerous female, about $11.5 \mathrm{~mm}$. long, carapace including rostrum 5.25 , telson about 1.5 , large chela 6 , and merus of third leg about $1.8 \mathrm{~mm}$. long.

Description. - At first glance with its more subequal, rather "squarish" frontal teeth, this species seems to belong with the brevicarpus group, which however, its well developed inferior prolongation of the rostrum definitely precludes. In the short stout legs there is a suggestion of $S$. sanlucasi Coutière (Proc. U. S. Nat. Mus., vol. 36, 1909, p. 41, text fig. 23) from Lower California, and S. heroni Coutière (op. cit., p. 42, text fig. 24) from Djibouti, but the dactyls of the third to fifth pairs of legs seem to have a somewhat different form. The annulations of the second legs closely approximate those of the latter species, and like it the inferior spine of the basicerite exceeds the stylocerite, but not so markedly. In our species the spine of the scaphocerite is shorter, though longer than the antennular peduncle, it is not as long as the carpocerite; moreover, the superior angle of the basicerite is but acute angled, not much produced, or spinous, a condition more common to the brevicarpus and laevimanus forms.

The frontal teeth are quite broadly triangular, the median rostral point less so than the lateral 
projections, and slightly exceeding them. The antennular peduncle is composed of rather short, squat, more or less sub-equal segments, both the carpocerite and the spine of the scaphocerite exceed it in length; the stylocerite reaches about to the middle of the second article, while the lateral spine of the basicerite reaches about to the distal margin of the same article of the antennular peduncle.

The large chela is slightly more than two and one half times as long as wide; the fingers are contained in the width one and one half times and not quite four times in the total length; the smaller chela is less than three times as long as wide, the fingers are longer than the width of the palm, by about one seventh their length and are contained in the total length of the hand about two and two thirds times; the dactyl of the smaller chela seems to have a small tooth near the tip, giving it a somewhat bifurcate appearance; in both of the chelipeds the meri are not produced or spinous anteriorly, above; the anterior margin of the palm of the large hand is unarmed.

The first article of the carpus of the second pair of legs is as long as the next three and three fourths of the distal article taken together, the second and fourth articles are subequal, and the third a little longer than either; the fifth article
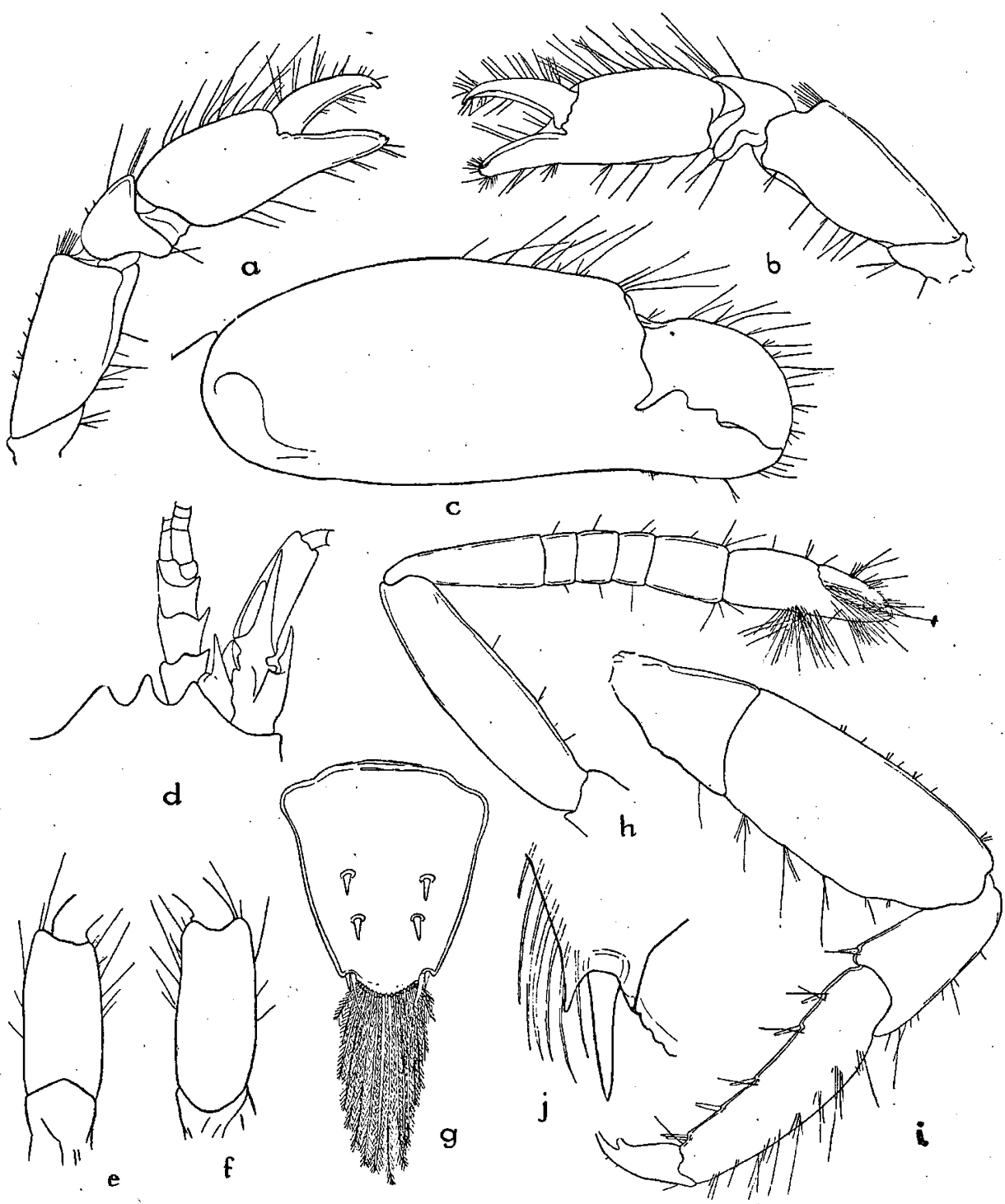

Fig. 3. - Synatphetus curaçaoensis, new species. a., b. Left cheliped. $c$. Right cheliped. d. Frontal region. $e ., f$. Carpocerite of right side. $g$. Telson. $h$. Second leg of right side.
$i$. Third leg of right side. $j$. Outer angle of external uropod.

is about as long as the third and either the second or fourth together; the chela is a little longer than the first article, and just about three times as long as wide.

In the stout third pair of legs the merus is about two and one fourth times as long as wide; the relative proportions of the leg otherwise being much as in $S$. nobili Coutière, (op. cit., p. 40, text fig. 22), from Ecuador; carpus 1, propodus 1.8, merus 2; the dactyl has a form differing from the other American forms to which this species otherwise seems to be related; the ventral hook is short, stout appearing, and blunt, being but very slightly more than one third the length of the terminal hook.

\section{Synalpheus brevicarpus (Herrick).}

Alpheus saulcyi var. brevicarpus HerRIck, Mem. Nat. Acad. Sci., vol. 5, 1891, p. 383.

Synalpheus brevicarpus Coutière, Proc. U. S. Nat. Mus., vol. 36, 1909, p. 50, text fig. 29.

Caracas Bay: 19. IV.20, 1 \% ovig.; from sponge, 10. V. 20, 5 specimens, (1 ovigerous); 19. V. 20 , 1 specimen Spanish Water: from Siderastrea, 29.IV.20, 1 specimen; 25. V.20, 8 specimens, (2 ovigerous). 
Synalpheus brevicarpus guérini Coutière.

Synalpheus brevicarpus Coutiere, Proc. U. S. Nat. Mus., vol. 36, 1909, p. 50, text fig. 30.

Spanish Water: from mangrove roots, 8. IV.20, 1 specimen; 26. IV.20, 1 specimen.

\section{Synalpheus goodei Coutière.}

Synalpheus goodei Coutıère, Proc. U. S. Nat. Mus., vol. 36, 1909, p. 58, text fig. 33.

Spanish Water: from Porites furcata, no date, 2 specimens ( 1 ovigerous); from Porites furcata, 14. IV, 20,

1 specimen; from Siderastrea, 29. IV. 20, 1 specimen; from Porites furcata, 5. V. 20, 7 specimens (3 ovig.). Caracas Bay: 19. IV. 20, 1 specimen.

Remarks. - The spines on the dorsal surface of the telson seem to be larger or stronger than in the nearly related S. longicarpus (Herrick) (vide Courière, op. cit., p. 53, text fig. 31); the middle, rostral tooth of the front is longer, and more parallel-sided, and the basicerite has a well marked superior projection or spine not evident in longicarpus.

Synalpheus pandionis Coutière.

Synalpheus pandionis CouTIËE, Proc. U. S. Nat. Mus., vol. 36, 1909, p. 67, text fig. 39; ZIMMER, Zool. Jahrb. 1913, suppl. 11, hft. 3, p. 385. text figs. C-E.

Caracas Bay: under stones at the shore, 3. V. 20, 1 o ovigerous.

Synalpheus, species?

(incomplete specimens not determined)

Spanish Water: from Porites furcata, 19. IV. 20, 1 specimen; 25. V. 20, 1 specimen.

Caracas Bay: from Maeandra, 7. IV. 20, 5 specimens; from Gorgonian, 10. IV. 20, 1 specimen.

\section{Jousseaumea trigona Rathbun.}

Jousseaumea trigona RathBun, Bull. U. S. Fish Comm., vol. 20, pt* 2, 1903 (1901), p. 111, text fig. 21. Spanish Water: 8. IV.20, 1 specimen in poor condition lacking chelipeds.

Family HIPPOLYTIDE.

Trachycaris rugosus (Bate).

Platybema rugosus Bate, Challenger Rept., Zool., vol. 24, 1888, p. 579, pl. 104, fig. 2; RathBun, Bull. U.S. Fish Comm., vol. 20, pt. 2, 1900 (1901), p. 113.

Trachycaris rugosus CaLmaN, Ann. Mag. Nat. Hist., ser. 7, vol. 27, 1906, p. 33, (in "Notes on some Genera of the Crustacean Family Hippolytidae").

Caracas Bay: 19. V. 20, 1 specimen.

\section{Hippolyte zostericola (Smith).}

Virbius zostericola SмIтн, Rept. U.S. Comm. Fisheries, pt. 1, for 1871-1872 (1873), p. 550, [256], pl. 3, fig. 11. Hippolyte zostericola RATHBUN, Rapport betreffende een voorloopig onderzoek naar den toestand van de Visscherij en de Industrie van Zeeproducten in de Kolonie Curaçao, uitgebracht door Prof. Dr. J. BoEKE, pt. 2, 1920, p. 322 [6].

Caracas Bay: between weeds from the boat, 1 specimen.

Spanish Water: 25. V. 20, 1 o ovig.

\section{Hippolyte curaçaoensis new species.}

Type locality. - West Punt: 14.V.20, 1 specimen, in poor condition.

Dimensions. - Total length about $7.5 \mathrm{~mm}$., rostrum 1, carapace 1.5 , and abdomen about $5 \mathrm{~mm}$. long.

Description. - Rostrum slender, armed above with three, more or less subequal teeth, the median is a little larger than the other two, which are about the same size; the intervals between the tip of the supra-orbital spine, the first tooth, the third tooth and the end of the rostrum are approximately equal, the second dorsal rostral tooth situated midway between the first and third and a little behind the middle of the rostrum; the rostrum is unarmed below, except for a small tooth immediately behind the acute tip giving it a bifurcate appearance; the rostrum is about two thirds the 
length of the carapace and attains the distal margin of the second segment of the antennular peduncle. The antennae are both wanting; the spine of the antennal scale is small and much exceeded by the blade.

The first of the three articles of the carpus of the second legs is the longest, being a little longer than the third, and about one and one third times longer than the second article; the hand is as long as the second and third articles taken together; the merus of this pair of legs equals the length of the first two articles and half the third taken together. The propodus of the third legs is much expanded, its greatest width being contained about three and one fourth times in the length; the dactyls terminate in three juxtaposed, subequal spines of considerable size, as compared with the smaller spines forming the row arming the lower or inner margin of the dactyl.'

Remarks. - This small species superficially has some resemblance to $H$. acuminata Dana (U.S. Expl. Exped., Crust., 1852, p. 562, atlas, 1855 , pl. 36 , figs. $1-1 \mathrm{e})$ and $H$. pleuracantha (Stimpson) (Ann. Lyc. Nat. Hist. N. Y., vol. 10, 1871, p. 127). Aside from the different form of the rostrum, the broader propodi of the ambulatory legs distinguish it from the more slender legged pleuracantha; the fifth abdominal somite is without the submedian teeth found on the posterior margin of the fifth abdominal somite of $H$. acuminata, in which species also the spine of the antennal scale is quite long, extending at least as far forward as, and often exceeding the blade.

All three species have the branchiostegal spine present and well developed. The ab-

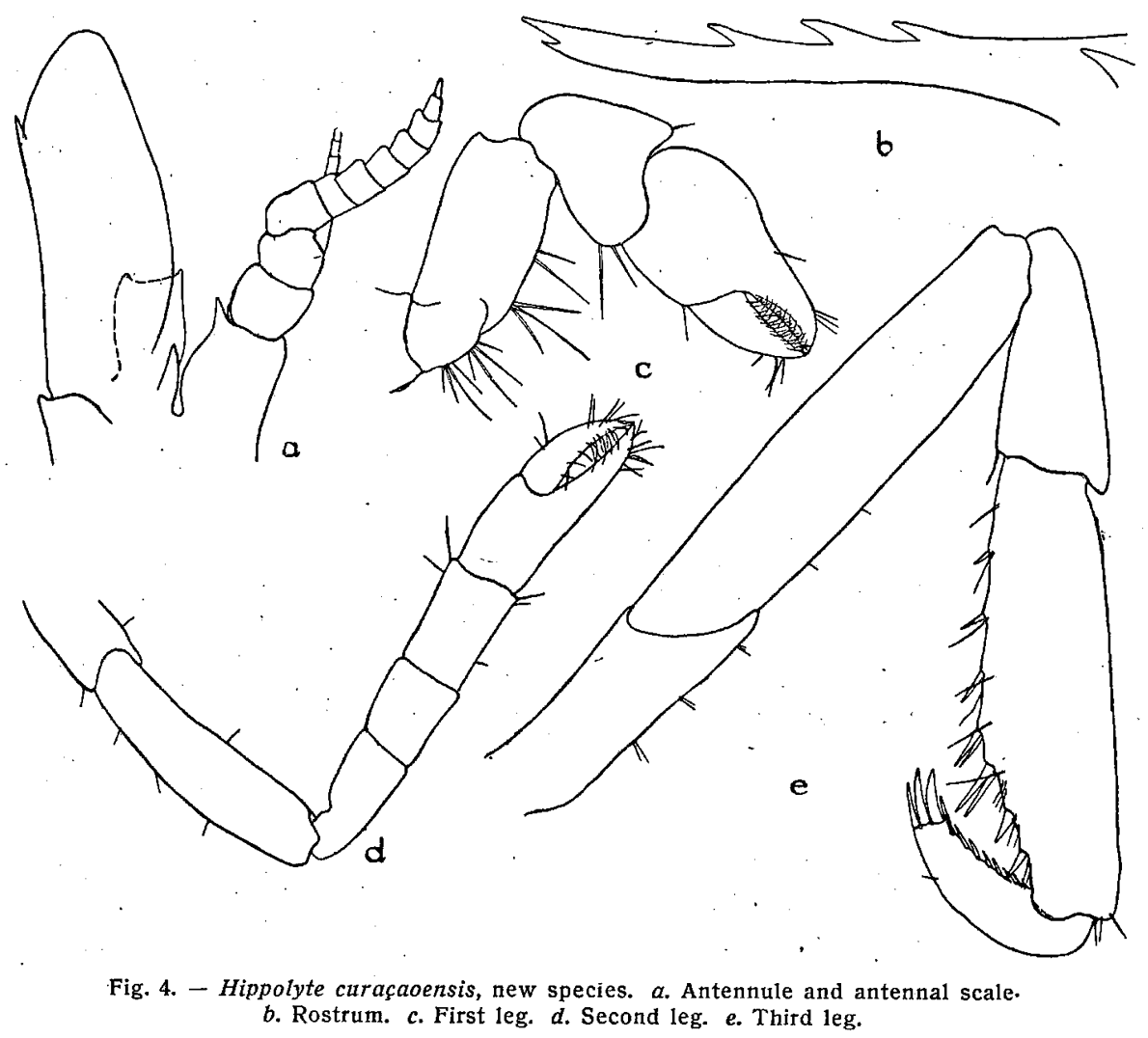
sence of the "hepatic" spine in $H$. acuminata mentioned by several authors seems to be but a reference to the fact that DANA failed to show the branchiostegal spine in his figure. (loc. cit., fig. 1a).

I have seen no specimens of $H$. exilirostratus Dana (op. cit., p. 563, pl. 36, figs. 2a-d), which appears to have a very similarly shaped rostrum. It has, however, four teeth above and none below, and though proportionately of about the same length as compared with the carapace, reaches about to the end of the antennular peduncle. The propodi of the ambulatory legs are similarly broadened but relatively more slender; the propodus of the third leg figured (loc. cit., fig. 2c), being about four and one half times as long as its greatest width. The hand of the second pair of legs is broader and has shorter fingers, and the carpal joints have somewhat different proportions. DANA's statement that the carpus of the second legs is "eight jointed" is at variance with his figure (loc. cit., fig. 2a) which shows but three articles characteristic of the genus. His specimen was "dredged at Rio Janeiro", and though he indicated no branchiostegal spine it seems almost safe to assume that it must have been present.

\section{Hippolysmata intermedia Kingsley.}

Hippolysmata intermedia Kingsley, Proc. Acad. Nat. Sci. Phila., vol. 30, 1878, p. 90 [2]; Rathbun, Bull. U. S. Fish Comm., vol. 20, pt. 2, 1900 (1901), p. 116; Rapport betreffende een voorloopig onderzoek naar den toestand van de Visscherij en de Industrie van Zeeproducten in de Kolonie Curaçao, uitgebracht door Prof. Dr. J. BoEkE, pt. 2, 1920, p. 322 [6].

Spanish Water: from Porites furcata, 4 specimens. 
Remarks. - Surely this species, but with a longer, slightly more slender rostrum, the acute tip reaching to the middle of the last segment of the antennular peduncle or beyond to end of peduncle. The rostra of two of the specimens had six teeth above, of which two were on the carapace, the other two had seven teeth above of which three were on the carapace; one of the dorsally six-toothed rostra had three teeth on the inferior margin, the others had but two teeth beneath, the usual number.

Thor paschalis (Heller).

Hippolyte paschalis HeLleR, Sitz.-ber., Akad. Wissen. Wien, vol. 44, 1861, p. 276, pl. 3, fig. 24.

Thor floridanus Kingsley, Proc. Acad. Nat. Sci. Phila., vol. 30, 1878, p. 95 [7]; Rathbun, Bull. U. S. Fish

Comm., vol. 20, pt. 2, 1900 (1901), p. 116; Rapport betreffende een voorloopig onderzoek naar den toestand van de Visscherij en de Industrie van Zeeproducten in de Kolonie Curaçao, uitgebracht door Prof. Dr. J. Boeke, pt. 2, 1920, p. 323 [7]; VerRiLl, Trans. Conn. Acad., vol. 26, 1922, p. 135, pl. 35, figs. 2-2f, pl. 41 , fig. 1 , pl. 46 , figs. $2-2$ e, pl. 47 , figs. 4,4 a.

Thor paschatis KeMP, Rec. Indian Mus., vol. 10, 1914, p. 95, pl. 1, figs. 6-10, and synonymy; Rec. Indian Mus., vol. 12, 1916, p. 387.

Caracas Bay: from Porites furcata, 7. IV. 20, 1 juvenile; 19. IV. 20, 2 specimens (1 ovigerous); from Porites furcata, 28. IV. 20, 6 specimens (4 ovigerous); 1. V. 20, 1 우 ovigerous.

Spanish Water: from Porites furcata, no date, 2 ovigerous; from Porites furcata, 14. IV. 20, 4 specimens (1 $ᄋ$ ovigerous, 1 juvenile ?); from Porites furcata, 5. V.20, 1 specimen; 10. V. 20, 2 ovigerous; 25. V. 20, 11 specimens (7 ovigerous).

Spanish Port: 10. IV. 20, 11 specimens (7 ovigerous).

\section{Family PONTONIIDE.}

Periclimenes rathbunae new species.

Type 1ocality. - Spanish Port: 20.V.20, 1 \%.

Dimensions. - Rostrum about $2.1 \mathrm{~mm}$. long, carapace and rostrum together about 6.5, abdomen exclusive of telson 10 , and telson about $3 \mathrm{~mm}$. long.

Description. - Rostrum projecting straight forward, tip reaching about to distal third of the antennular peduncle, deep in lateral view; armed above with six teeth of which two are behind

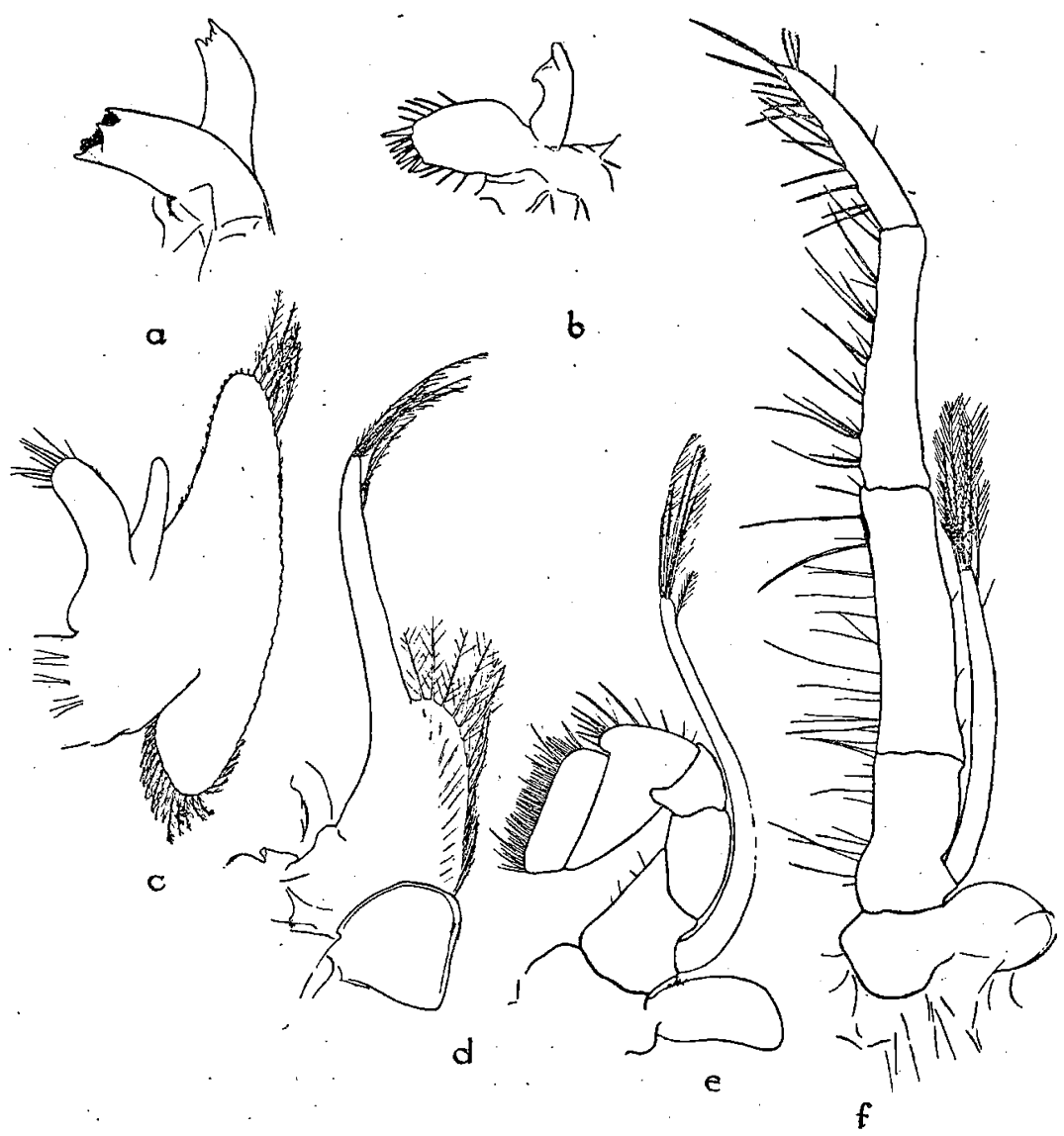

Fig. 5. - Periclimenes rathbunae, new species. $a$. Mandible. b. Maxillula, outer lacina lost. c. Maxilla. $d$. Exopodite of first maxilliped. e. Second maxilliped. $f$. Third maxilliped. the orbit, the second tooth is about as far removed from the first as it is from the fourth, but otherwise the teeth are quite evenly spaced, the last tooth is one and about one third times as far from the acute tip of the rostrum as it is from the penultimate tooth; below the rostrum is unarmed. The antennal and hepatic spines are well developed, the latter being about one and a half times as far behind the antennal spine as it is below its level.

The lateral process of the basal antennular segment reaches about to the middle of the segment which distally in addition to the spinous antero-external angle, has an acute angled projection lying partly beneath the second segment of the peduncle; the shorter free portion of the outer flagellum is composed of three short segments, the fused part of nine. The blade of the antennal scale extends well beyond the spine. All three maxillipeds are provided with exopodites. 
The fingers of the first legs are long and slender, but shorter than the palm, the hand and carpus are subequal and about one seventh their length shorter than the merus. Second legs dissimilar, the left one having a much heavier chela with shorter fingers; the dactyl of this larger hand is quite deep, being a little less than twice as deep as the immovable finger at about the middle of its length; measured from its tip to the articulation, the dactyl is about two thirds the length of the rest of the hand; in the smaller hand of the second pair of legs, the dactyl is, if anything more slender than the fixed finger, the former measured from its tip to the articulation is almost as long as the palm. The cutting edges of the chelae seem to be without teeth. There are no spines in evidence on any of the legs. The last three pair of legs are similar with rather slender, simple dactyls and quite slender propodi, about eight times as long as wide.

The telson is much like that of $P$. brevicarpalis Schenkel (vide KEMP, Rec. Indian Mus., vol. 24, 1922 , p. 189 and text fig. 42 ), but the longer terminal spines are about three fourths the width of the end of the telson, instead of one half as in that species.

Remarks. - Our species has a number of points of resemblance to $P$. brevicarpalis Schenkel (Verh. naturf. Ges. Basel, vol. 13,1902 , p. 563, pl. 13, figs. $21 \mathrm{a}-\mathrm{m})$ near which it keys out in KEMP's analysis (op. cit., p. 168) of the subgenus Ancylocaris. From that species it may be distinguished by the different form of the antennules, the dimorphism of the second legs and the more slender three posterior pairs of legs.

The carapace is not swollen dorsally, though quite broad, and

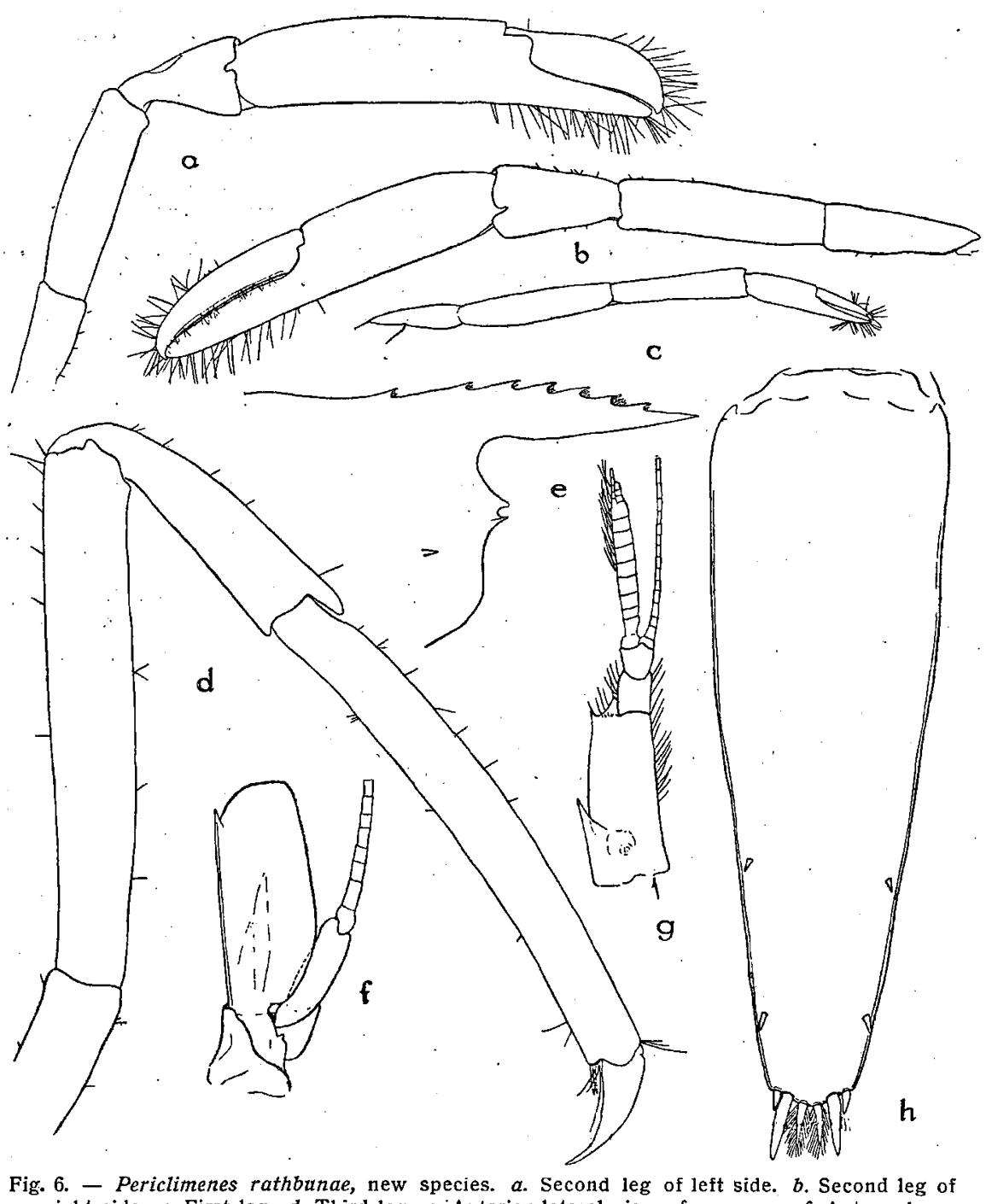
Fig. 6. - Periclimenes rathbunae, new species. $a$. Second leg of left side. $b$. Second leg of
right side. $c$. First leg. $d$. Third leg. e. Anterior lateral view of carapace. $f$. Antennal scale and peduncle. g. Antennule. $h$. Telson.

shows some degree of areolation, the cervical groove being faintly discernible across the dorsum of the carapace, but otherwise there is no resemblance to the genus Dasycaris Kemp (op. cit., p. 240), the antennal and hepatic spines are not each flanked by a strong carina, and are not at the same level, the basal segment of the antennular peduncle is normally broadened and the third to fifth abdominal somites are broadly rounded, not drawn out inferiorly into long acute processes.

The antennules of our species are not unlike those of $P$. diversipes Kemp (op. cit., p. 179, text figs. 36-39), which has the fused portion of the outer flagellum composed of seven to nine segments and the shorter free portion of three, and the lateral process of the basal segment reaching its middle; similar too are the slender ambulatory legs. However, the difference in the size and position of the spines on the dorsum of the telson, and the fact that in diversipes the hepatic spine is placed on a level with the antennal spine at once sets the two apart.

Though the inner lacina of the maxillula became broken off and lost, the character of the rostrum alone precludes any affinity with the genera Anchistus and Pontonia. 
Pontonia grayi. Rathbun.

Pontonia grayi Rathbun, Bull. U. S. Fish Comm., vol. 20, pt. 2, 1900 (1901), p. 122, text fig. 25.

Caracas Bay: from buoy, 7. IV. 20, 1 specimen without legs.

\section{Family PALAEMONIDF. \\ Palaemon affinis M.-Edw.}

Palaemon affinis Milne Edwards, Hist. Nat. Crust., vol. 2, 1837, p. 391; Rathbun, Bull. U.S. Fish Comm., vol. 20, pt. 2, 1900 (1901), p. 125; VerRILL, Trans. Conn. Acad., vol. 26, 1922, p. 142, pl. 43, figs. 3, 3b, pl. 47 , fig. 7 , pl. 48 , figs. $4-4$ d.

Spanish Water: from mangrove roots, 8. IV.20, 1 우 ovigerous.

Caracas Bay: from small pool between mangroves, 1 specimen.

\section{Palaemon paulensis (Ortmann).}

Leander paulensis ORtMAnN, Revista Mus. Paulista, vol. 2, 1897, p. 192, pl. 1, fig. 14; RATHBUN; Bull. U.S. Fish Comm., vol. 20, pt. 2, 1900 (1901), p. 125.

Spanish Port: 10. IV.20; 1 specimen.

Spanish Water: 25. V.20, 1 specimen.

Remarks. - These specimens are much like those identified by Miss Rathbun (loc. cit.) with this species, though the rostrum is basally not quite so deep; the palm and fingers are nearly subequal, but the carpus is a little longer than either.

\section{Palaemon tenuicornis Say.}

Palaemon tenuicornis SAY, Journ. Acad. Nat. Sci. Phila., vol. 1, 1818, p. 249; RATHBun, Rapport betreffende een voorloopig onderzoek naar den toestand van de Visscherij en de Industrie van Zeeproducten in de Kolonie Curaçao, uitgebracht door Prof. Dr. J. Boeke, pt. 2, 1920, p. 323 [7]; Verrill, Trans. Conn. Acad., vol. 26,1922 , p. 143 , pl. 43, figs. 4 , 4 a.

Spanish Port: 10.IV.20, 1 specimen.

Macrobrachium savignyi (Bate).

Brachycarpus savignyi BATE, Challenger Rept., Zool., vol. 24, 1888, p. 795, pl. 129, fig. 4.

Bithynis savignyi RATHBun, Bull. U. S. Fish Comm., vol. 20, pt. 2, 1900 (1901), p. 124

Palaemon savignyi Verrill, Trans. Conn. Acad., vol. 26, 1922, p. 145, text fig. 11.

Macrobrachium savignyi RATHBUN, Rapport betreffende een voorloopig onderzoek naar den toestand van de Visscherij en de Industrie van Zeeproducten in de Kolonie Curaçao, uitgebracht door Prof. Dr. J. BoEKE, pt. 2, 1920, p. 324 [8].

Spanish Water: 25. V. 20, 2 specimens (1 ovigerous).

\section{Family GNATHOPHYLLIDF.}

Gnathophyllum americanum Guérin.

Gnathophyllum americanim GUÉRIN, in LA SAGRA's. Hist. Cuba, vol. 7, 1857, p. 20, atlas, vol. 8, pl. 2, fig. 14; Rathbun, Bull. U. S. Fish Comm., vol. 20, pt. 2, 1900 (1901), p. 126; Rapport betreffende een voorloopig onderzoek naar den toestand van de Visscherij en de Industrie van Zeeproducten in de Kolonie Curaçao, uitgebracht door Prof. Dr. J. BoEKE, pt. 2, 1920, p. 325 [9]; VerRill; Trans. Conn. Acad., vol. 26, 1922, p. 150 , pl. 16 , fig. 7 , pl. 41 , fig. 3 , pl. 46 , figs. $1-1$ k, pl. 48 , figs. 5,5 a.

Spanish Water: from Porites furcata, 13. IV.20, 1 specimen; 14.1V.20, 2 specimens.

Family LySMATIDE.

Processa canaliculata Leach.

Processa canaliculata LEACH, Mal. Podoph. Brit., pl. 41 and corresponding text, July 1, 1815; RATHBUn, Bull. U. S. Fish Comm., vol. 20, pt. 2, 1900 (1901), p. 104; VerRILL, Trans. Conn. Acad., vol. 26, 1922, p. 138 , pl. 16 , figs. 6,6 b, pl. 41 , fig. 4 , pl. 47 , figs. 8 , a-b.

Caracas Bay: from Maeandra, 7.IV. 20, 19 ovigerous.

Family STENOPIDE.

Stenopus hispidus (Olivier).

Palaemon hispidus OlivieR, Encyc. Méth., Hist. Nat.; Insectes, vol. 8, 1811, p. 666, tabl. 1818, pl. 319, fig. 2. 
Stenopus hispidus RankIN, Ann. N. Y. Acad. Sci., vol. 11, 1898, p. 240, pl. 29, fig. 1. RathBun, Rapport betreffende een voorloopig onderzoek naar den toestand van de Visscherij en de Industrie van Zeeproducten in de Kolonie Curaçao, uitgebracht door Prof. Dr. J. BoEkE, pt. 2, 1920, p. 325 [9]. VerRILL, Trans. Conn. Acad., vol. 26, 1922, p. 36, pl. 9, figs. 5-5b, pl. 11, fig. 1, pl. 12, figs. 1, 2.

Caracas Bay: 19. IV. 20, $1 \sigma^{7}$.

\section{Stenopus spinosus Risso.}

Stenopus spinosus Risso, Hist. Nat. de l'Eur. Mérid., vol. 5, 1826, p. 66, pl. 3, fig. 8. RATHBun, Rapport betreffende een voorloopig onderzoek naar den toestand van de Visscherij en de Industrie van Zeeproducten in de Kolonie Curaçao, uitgebracht door Prof. Dr. J. BoEKe, pt. 2, 1920, p. 325, [9].

Stenopus scutellatus RANKIN, Ann: N. Y. Acad. Sci., vol. 11, 1898, pl. 29, fig. 3.

Caracas Bay: from sponge, 10. V.20, 1 q ovigerous.

\section{Family PALINURIDÆ.}

Panulirus species.

Caracas Bay: 19. IV. 20, 1 specimen of the natant "puerulus" stage of Panulirus.

Remarks. - This is probably the natant stage of Panulirus argus (Latreille) found to be of frequent occurrence at Curaçao by Miss RATHBUN (Rapport betreffende een voorloopig onderzoek naar den toestand van de Visscherij en de Industrie van Zeeproducten in de Kolonie Curaçao, uitgebracht door Prof. Dr. J. BoEkE, pt. 2, 1920, p. 326 [10]). I am reluctant to attempt to more definitely place this specimen owing to our great dearth of knowledge regarding the life histories of the Panulirids.

\section{Family PORCELLANIDÆ.}

Petrolisthes galathinus (Bosc).

Porcellana galathina Bosc, Hist. Nat. Crust., vol. 1, 1802, p. 233, pl. 6, fig. 2.

Petrolisthes sexspinosus RATHBUN, Ann. Inst. Jamaica, vol. 1, no: 1,1897, p. 40; Proc. Wash. Acad. Sci., vol. 2, 1900, p. 145; Benedict, Bull. U. S. Fish Comm., vol. 20, pt. 2, 1900 (1901), p. 133.

Petrolisthes galathinus RATHBUN, Rapport betreffende een voorloopig onderzoek naar den toestand van de Visscherij en de Industrie van Zeeproducten in de Kolonie Curaçao, uitgebracht door Prof. Dr. J. BOEKE, pt. 2, 1920, p. 327 [11].

Spanish Water: from Porites furcata, 7. IV. 20, $5 \sigma^{7} 1$ \%; from Porites furcata; 13. IV. 20, $28 \sigma^{7} 37$ ( (32 ovig.); from Porites furcata, 14. IV.20, 36 specimens; from Porites furcata, $4 \sigma^{7}$; from sponge, 19. IV.20, 1 \% ovigerous; from Porites furcata, 5. V. 20, $90^{7} 19$ ㅇ (12 ovig.).

Caracas Bay: from Porites furcata, 3. V. 20, 1 q.

Petrolisthes marginatus Stimpson.

Petrolisthes marginatus Stimpson, Ann. Lyc. Nat. Hist. N. Y., vol. 7, 1859 (1860), p. 74 [28]; BenEDict, Bull. U. S. Fish Comm., vol. 20, pt. 2, 1900 (1901), p. 134, pl. 3, fig. 1.

Caracas Bay: under stone at the shore, 3. V.20, 1 . .

Petrolisthes quadratus Benedict.

Petrolisthes quadratus Benedict, Bull. U. S. Fish Comm., vol. 20, pt. 2, 1900 (1901), p. 134, pl. 3, fig. 4.

Caracas Bay: under stones at the shore, 3. V. $20,2 \sigma^{\pi} 3$ ㅇ ( 1 ovigerous).

Petrolisthes nodosus Streets. (Pl. VIII, fig. 8).

Petrolisthes nodosus Streets, Proc. Acad. Nat. Sci. Phila., vol. 24, 1872, p. 133; Benedict, Bull. U. S. Fish Comm., vol. 20, pt. 2, 1900 (1901), p.. 134.

Spanish Bay: between stones in the surf, 11. V.20, $1 \delta^{7} 2$ ovigerous.

Petrolisthes vanderhorsti, new species. (P1. VIII, fig. 7).

Type-locality. - Caracas Bay: from Maeandra, 7.IV. 20, $1 \sigma^{7}$ holotype.

Dimensions. - Length of carapace $5 \mathrm{~mm}$., width 4.75 , width of front 1.75 , length of front, in advance of supra-orbital notch $5 \mathrm{~mm}$.

Description. - In general appearance suggestive of $P$. nodosus Streets, less nodular and 
more evenly granular. Front similar but much more produced, teeth less acute, apices of lateral projections directed anteriorly. On either side of the produced, tridentate front there is a slight notch above and a little before the eye, marking the beginning of the straight oblique, raised margin of the orbit; behind the eye there is a prominent post-orbital tooth forming a rather right angle with the orbital margin as viewed from above. Marking the beginning of the faint cervical groove the anterior lateral margins of the carapace are narrowly incised. The entire upper surface of the carapace is rather coarsely granular, laterally on the branchial regions and posteriorly the granules tend to form slightly imbricated, indistinct, transverse ridges.

Upper surface of chelipeds granulated like anterior portion of carapace, granules becoming transversely elongated on the carpus. Fingers about two fifths the length of the entire hand, inner. margins in close contact, tips strongly hooked; movable finger with external margin very slightly concave, immovable convex, the former at about the middle of its length about half as wide as immovable finger; paralleling the outer margin of the hand is a wide, shallow groove or depression, widest just behind the base of the fixed finger, posteriorly from that point to the postero-external angle of the palm, the outer slope of the shallow longitudinal groove to the outer edge of the palm, carries a not very dense pubescent brush. The carpus has two longitudinal grooves, the outer being in effect, a continuation of the groove on the hand lying just within the inflated posterior margin of the carpus, the anterior running just below the bases of the four sharp teeth which arm the inner margin of the carpus. Of these teeth the proximal one is the longest, the distal the smallest, though the teeth become broader, as well as shorter distally; their margins, particularly those of the first tooth are more or less distinctly, finely sawtoothed. The posterior margin of the carpus is prolonged distally into an upcurved tooth, about as long as the second tooth on the anterior margin.

The ambulatory legs are not hairy; there are only a few scattered hairs on the under side of the dactyls and near the distal ends of the propodi.

Remarks. - In this species, as in $P$. nodosus Streets the single anterior epimeral plate of the carapax characteristic of this genus, is followed by numerous smaller, as it were, fragmented pieces, all separated from one another by membranous interspaces. In no sense do the epimera approach those of Pachycheles, but they are decidedly unique among the species of Petrolisthes I have had the opportunity to examine.

Petrolisthes jugosus Streets.

Petrolisthes jugosus Streets, Proc. Acad. Nat. Sci. Phila., vol. 24, 1872, p. 134; Benedict, Bull. U. S. Fish Comm., vol. 20, pt. 2, 1900 (1901), p. 134.

Caracas Bay: from Maeandra, 7.IV.20, $1 \delta^{7} 2$ o ovigerous; under stones at the shore, 3. V.20, $1 \delta^{7} 1$ 우 ovig. West Punt: 14. V.20, $1 \sigma^{7}$.

\section{Petrolisthes amoenus (Guérin).}

Porcellana amoena GUÉRIN, in LA SAGRA's Hist. Cuba, pt. 2, vol. 8, atlas 1857, pl. 2, fig. 2. Petrolisthes ? amoenus Benedict, Bull. U. S. Fish Comm., vol. 20, pt. 2, 1900 (1901), p. 135, pl. 3, fig. 3.

Caracas Bay: from Porites furcata, 28. IV. 20, 2 ㅇ (1 ovigerous); 1. V. 20, 1 우 5. V. 20, $1 \sigma^{7}$; from Porites furcata, 5. V. 20, 2 \%; from sponge, 2 ( 1 with rhizocephalid parasite).

Petrolisthes magnifica (Gibbes).

Porcellana magnificus GibBes, Proc. Amer. Assoc. Adv. Sci., vol. 3, 1850, p. 191 [27].

Petrolisthes magnifica Benedict, Proc. U. S. Nat. Mus., vol. 16, 1893, p. 539; Rathbun, Rapport betreffende een voorloopig onderzoek naar den toestand van de Visscherij en de Industrie van Zeeproducten in de Kolonie Curaçao, uitgebracht door Prof. Dr. J. BoEKE, pt. 2, 1920, p. 327 [11].

Caracas Bay: 1. V.20, $3 \sigma^{7} 2$ ㅇ.

Pisosoma angustifrons Benedict.

Pisosoma angustifrons Benedict, Bull. U. S. Fish Comm., vol. 20, pt. 2, 1900 (1901), p. 135, pl. 3, fig. 6.

Caracas Bay: from Maeandra, 7.IV.20, $1 \delta^{\top} 1$ 우 ovigerous; between roots of a Gorgonian, 10. IV.20, $3 \sigma^{\text {入 }}$ $5 \%$ ovigerous.

Spanish Bay: 11. V.20, 19 ovigerous; between stones in the surf, 11. V.20, 37 specimens (3 with branchial parasites). 
Remarks. - Benedict considers this species very near P. greeleyi Rathbun (Proc. Wash. Acad. Sci., vol. 2, 1900, p. 147, pl. 8, fig. 4), but the latter proves to be a Pachycheles having the epimera of the carapace posteriorly broken up, with a posterior subquadrate part separated by a cutaneous interspace from the remainder.

Pisosoma curaçaoensis new species. (Pl. VIII, figs..1, 2, 3).

Type-1ocality. - Spanish Bay: between stones in the surf, 11. V. 20, $33 \sigma^{7} 26 \%$ (21 ovigerous).

Dimensions. - An ovigerous female of fair size has the carapace $4.25 \mathrm{~mm}$. wide, most of the specimens are however smaller than this.

Description. - Carapace about as long as wide, or a little longer, in the males it is a little longer and in the females broader; front a little produced in the middle much like that of Petrolisthes quadratus as figured by BenEdict (Bull. U. S. Fish Comm., vol. 20, pt. 2, 1900 (1901), pl. 3, fig. 4); "shoulder" of carapace behind cervical groove prominent.

Chelipeds and hands short and stout, fingers short, movable one closing nearly transversely, immovable one almost as broad at base as long and only about half the length of the movable finger; fingers of larger hand blunt and quite worn looking, those of the smaller hand more pointed; the immovable finger of the larger hand has a blunt angle or tooth at about the middle of its inner margin, while the movable finger has a blunt tooth on the inner margin near its base.

In just about two fifths of the specimens, the outer third of either hand from about the base of the fixed finger to the postero-external angle of the palm carries a brush, or felt, of rather thick dense pubescence; another two-fifths, approximately, have such pubescence only on the smaller hand, while the remaining fifth of the specimens has both hands naked. This seems to be a very peculiar circumstance for in a number of Porcellanids the presence or absence of such a brush of hair seems to be quite a fixed specific character, but between the specimens of this species of various degrees of pubescence, I can find no other differences, which in the least differentiate them. An inspection of those with both hands carrying the pubescence would almost seem to indicate that it occurred normally on the smaller hand, and that hands regenerated in place of lost larger hands secondarily had become provided with the "brush", for within this two-fifths of the specimens, the hands all appear to be a more or less subequal and much of the same general character of the usual smaller hand in the other specimens, not exhibiting the differentiation between the larger and smaller hands normal to the genus and to a greater or lesser extent among all Porcellanids. Though this is a somewhat plausible explanation why half of four fifths of the specimens should differ from the other half, it does not account for the lack of the brush of hair on the hands of the remaining fifth of the specimens. It is possible that the pubescence of the smaller hand, at least of these specimens, had become lost in some way; among twelve specimens not considered above because one or the other hand was wanting, there was one with just a small tuft of pubescence remaining near the postero-external angle of what appeared to be a "smaller" hand.

The carpus has an irregular $W$-shaped impression on its upper surface, with the opening of the $\omega$ toward the meral articulation; the ridges between the sulci forming the impression are granulated, or minutely nodulated, as is also the upper surface of the merus of the chelipeds, the hands are rather more evenly granular, the anterior margin of the carpus is armed with usually five, rarely four, blunt, flattened, conical teeth, counting the antero-distal angle, edges of teeth apparently entire, showing under the glass, however, the granulations of the dorsal surface of the carpus along their margins; the well marked sinuses between the teeth are filled with pubescence. The ambulatory legs of all the specimens are very hairy.

Remarks. - Of the forty seven specimens having both hands, $1 \sigma^{7} 18$ (17 ovigerous) had the brush of pubescence on both hands, $19 \sigma^{7}$ had it only on the smaller hand, and $7 \sigma^{7} 2$ ( 1 ovigerous) lacked the pubescence on the hands entirely:

It would almost seem that the presence of the pubescence on both hands was a female character, a suggestion that seems to be borne out by the fact that both chelipeds in the double brushed forms were of the "smaller" hand type, but as will be noted $2 \%$ ( 1 ovig.) had no hair on either hand, and one male, it is true a very tiny one, had the "brush" on both hands. 
Of the twelve specimens with only one cheliped, the hand in $3 \sigma^{7} 69$ ( 3 ovigerous). showed at least some evidence of the pubescent brush, in the other $3 \sigma^{7}$ specimens, it was completely waniing.

\section{Megalobrachium poeyi (Guérin).}

Porcellana poeyi GuÉRIN, in LA SAGRA's Hist. Cuba, pt. 2; vol. 8, atlas 1857, pl. 2, fig. 4. Megalobrachium poeyi BENEDICT, Bull. U. S. Fish Comm, vol. 20, pt. 2, 19CJ (1901), p. 136, pl. 3, fig. 8. Spanish Water: sieved out of the sand, 4. V.20, $1 \%$.

Pachycheles pilosus (H. Milne Edwards).

Porcel'ana pilosa H. Milne Edwards, Hist. Nat. Crust., vol. 2; Benedict, Bull. U. S. Fish Comm., vol. 20, pt. 2, 1900 (1901), p. 137, pl. 3, fig. 11.

Caracas Bay: from Maeandra, 7. IV. 20, $1 \delta^{\nearrow} 1$ o ovigerous; 5. V. 20, $1 \delta^{\lambda} 1$ o ovigerous.

Remarks. - This species, at least as recognized by American authors, is an undoubted Pachycheles, having the divided epimera, and the hirsute, turned down front, and characterisiic chelae of that genus.

Family AxianASSID $Æ$ new family.

Characters. - Thalassinidea with rostrum of moderate size; with linea thalassinica present, it, as well as, - cervical gioove being well marked, antennular flagella of moderaie lengíh; movable antennal thorn, (antennal scale) well developed, no immovable antennal thorn; leogs of the first pair large, dissimilar, chelate; those of the second, third and fourth pairs, simple, and those of the fiith pair imperfectly subchelate; no gill, only a tiny epipodite on the first maxilliped; epipodites and podobranchs and two arthrobranchs on the second and third maxillipeds and the first inree pair of legs, arthrobranchs of the second maxillipeds rudimentary, having only about one fourih the number of filaments found on the other appendages; fourth pair of legs with small epipodite and two arthrobranchs, fifth legs without gills of any description; no pleurobranchs; gills trichobranchiate with narrow filaments; pleura of abdominal segments very poorly developed, almost wanting; abdominal limbs without appendix interna; branches of uropods unjointed without trace of a suture.

The branchial formula is as follows:

\begin{tabular}{|c|c|c|c|c|}
\hline $\begin{array}{l}\text { Somites and } \\
\text { Appendages. } \\
\text { VII }\end{array}$ & $\begin{array}{c}\text { Podobranchiae. } \\
\text { ep. }\end{array}$ & $\begin{array}{c}\text { Arthrobranchiae. } \\
0\end{array}$ & $\begin{array}{c}\text { Pleurobranchiae. } \\
0\end{array}$ & ep. \\
\hline VIII & $1+$ ep. & 2 reduced & 0 & $=3+\mathrm{ep}$. \\
\hline IX & $1+$ ep. & 2 & 0 & $=3+\mathrm{ep}$ \\
\hline $\mathrm{X}$ & $1+$ ep. & 2 & 0 & $=3+\mathrm{ep}$ \\
\hline $\mathrm{XI}$ & $1+\mathrm{ep}$ & 2 & 0 & $=3+\mathrm{ep}$ \\
\hline XII & $1+$ ep. & 2 & 0 & $=3+\mathrm{ep}$ \\
\hline XIII & ep. & 2 & 0 & $=2+\mathrm{ep}$ \\
\hline XIV & 0 & -0 & 0 & 0 \\
\hline & $5+7$ ep. & 12 & 0 & $=17+7 \mathrm{ep}$. \\
\hline
\end{tabular}

One genus, Axianassa, with the characters of the family; one species.

Remarks. - In order to portray the relationship of this family to the others comprising the tribe, the following table is presented: (see p. 77).

As will be observed, the combination of characters exhibited by the specimens upon which the erection of this family is attempted is such as to admit their satisfactory inclusion in none of the existing families comprising the Thalassinidea. Some of the characters are common to the Axiidae, others to the Callianassidae, to a greater extent than the Laomediidae and Thalassinidae. In the presence of the movable antennal thorn, epipodites on the first four legs, and podobranchs on the first three, the Axiidae are called to mind, while the linea thalassinica, the lack of the immovable antennal thorn, the poorly developed, almost wanting, abdominal epimera point toward Callianassid affinities. 


\begin{tabular}{|c|c|c|c|c|c|}
\hline & AXIIDA. & AXIANASSID E. . & LAOMEDIIDF. & ThALASSINIDF. & CALLIANASSID $Æ$. \\
\hline Rostrum & Of good size & Of moderate size & Of good size & Of fair size & $\begin{array}{l}\text { Of good size or } \\
\text { small }\end{array}$ \\
\hline Linea thalassinica & Wanting & Present & Present & Present & Present or wanting \\
\hline Antennular flagella & Of good length & Moderate length & Rather short & Moderate & Short or moderate \\
\hline $\begin{array}{c}\text { Movable antennal } \\
\text { thorn (antennal } \\
\text { scale) }\end{array}$ & Present & Present & Wanting? & Wanting & Quite vestigial \\
\hline $\begin{array}{l}\text { Immovable anten- } \\
\text { nal thorn }\end{array}$ & Present $\ldots . .$. & Wanting & Wanting & Wanting & Wanting \\
\hline First legs & $\begin{array}{l}\text { Chelate, large, un- } \\
\text { equal }\end{array}$ & $\begin{array}{l}\text { Chelate, large, dis- } \\
\text { similar }\end{array}$ & $\begin{array}{l}\text { Chelate, large, } \\
\text { equal }\end{array}$ & Subchelate & $\begin{array}{l}\text { Chelate, subchelate, } \\
\text { or simple }\end{array}$ \\
\hline Second legs & $\begin{array}{l}\text { With small, equal } \\
\text { chelae }\end{array}$ & Simple & $\begin{array}{l}\text { Simple or sub- } \\
\text { chelate }\end{array}$ & Subchelate & Chelate or simple \\
\hline Fifth legs & Simple & $\begin{array}{l}\text { Imperfectly sub- } \\
\text { chelate }\end{array}$ & Subchelate & Simple & $\begin{array}{l}\text { Simple, subchelate, } \\
\text { or chelate }\end{array}$ \\
\hline Epipodites on legs & $1-4$ & $1-4$ & $1-4$ & $1-4$ & Usually without \\
\hline $\begin{array}{l}\text { Podobranchs on } \\
\text { legs }\end{array}$ & $1-3$ or 4 & $1-3$ & $1-3 ?$ & $1-3$ & Wanting \\
\hline Abdominal pleura & $\begin{array}{l}\text { Well or moderately } \\
\text { well developed }\end{array}$ & Almost wanting & $\begin{array}{l}\text { Fairly well devel- } \\
\text { oped }\end{array}$ & Small & Almost wanting \\
\hline $\begin{array}{l}\text { Exopodite of uro- } \\
\text { pods }\end{array}$ & $\begin{array}{l}\text { With or without } \\
\text { suture }\end{array}$ & Without suture & With suture & Without suture & Without suture. \\
\hline
\end{tabular}

The family seems to occupy a position intermediate between the Axiidae and the Callianassidae, of which its name is intended to be indicative.

Axianassa intermedia new species. (Pl. VIII, figs. 4, 5).

Ty pe-locality. - Spanish Port: from a muddy creek, 17. IV. 20, $20^{7} 4 \%, 1$ juvenile.

Additional specimen. - Caracas Bay: 19. IV. 20, 1 immature.

Dimensions. - Of largest specimen, a female, carapace and rostrum together $8.5 \mathrm{~mm}$. long, rostrum $5 \mathrm{~mm}$, distance from posterior margin of carapace to base of telson $191 / 2 \mathrm{~mm}$., telson about $3.25 \mathrm{~mm}$. long, and of about the same width; of figured male specimen, carapace and rostrum $8.2 \mathrm{~mm}$., from posterior margin of carapace to base of telson $19 \mathrm{~mm}$., telson $3 \mathrm{~mm}$. long, greatest width $2.75 \mathrm{~mm}$., large hand $10.5 \mathrm{~mm}$. long from tip of fixed finger to postero-superior angle, movable finger from tip to articulation $4.5 \mathrm{~mm}$. long, palm $5.25 \mathrm{~mm}$. wide; small hand measured as above $10.5 \mathrm{~mm}$. long, movable finger $5 \mathrm{~mm}$., least width of palm $4 \mathrm{~mm}$. at point just behind bases of fingers, greatest width $4.5 \mathrm{~mm}$.

Description. - Whole carapace, abdomen and appendages beset with more or less evenly scattered hairs; when wet entire surface has at first glance an almost prickly appearance.

Rostrum of moderate length, exceeding eyestalks, flattened, triangular, with rounded apex; eyestalks flattened, distally narrowed, a little divergent and slightly upturned, cornea terminal, appearing to extend backward into body of stalk as a longitudinal, pigmented strand of tissue.

Movable antennal thorn well developed, fixed one wanting, about two fifths as long as the terminal segment of the antennular peduncle which attains about the middle of the penultimate article of the antennal peduncle; on the inner margin of the antennal thorn, from one fourth to one third the length of the scale above its base, there is a small, sharp spine. Terminal segment of antennular peduncle and penultimate of antennal peduncle long and slender; just a triangular portion of the first joint of the antennal peduncle half the length of the second joint shows beyond the frontal margin of the carapace, the second joint shorter than the movable thorn, between two thirds and three fourths its length, the movable thorn extending along about one fourth the length of the fourth or penultimate joint of the antennal peduncle, the third joint in dorsal view concealed by the second, and the antennal thorn, fifth joint about as long as the second. Longer antennular flagellum about as long as the portion of the carapace before the cervical groove exclusive of the rostrum, shorter flagellum only about half as long; antennal flagellum as long as the carapace and the first abdominal segment together. The mandible carries a three jointed palp, the end joint of which is longer and heavier than 
the others and tucked in behind the cutting edge as viewed from below; there is no exopodite on the pediform third maxillipeds, though present on the first and second maxillipeds.

Chelae of first legs dissimilar; larger hand, more or less rectangular fingers about two sevenths the length of the entire chela, movable finger closing at angle of about $45^{\circ}$, tip crossing inside of tip of fixed finger, furnished with two low teeth, situated at either end of the middle third of the inner margin, distal to outer and proximal to the inner of these teeth are two smaller teeth; on the fixed finger there is one tooth just behind the middle of its inner margin and several small denticulations close together at its base; carpus, small triangular with one or two small teeth or tubercles on the outer hinder margin about one third the length of the margin from the infero-distal angle; merus ovoid, upper and lower margins sharply carinated, the latter denticulate; smaller hand about as long as the larger, with greatest width nearly as great as in larger, upper margins straight, lower with a decided convexity near the posterior end, fingers slender extended in line of major axis of hand, tip

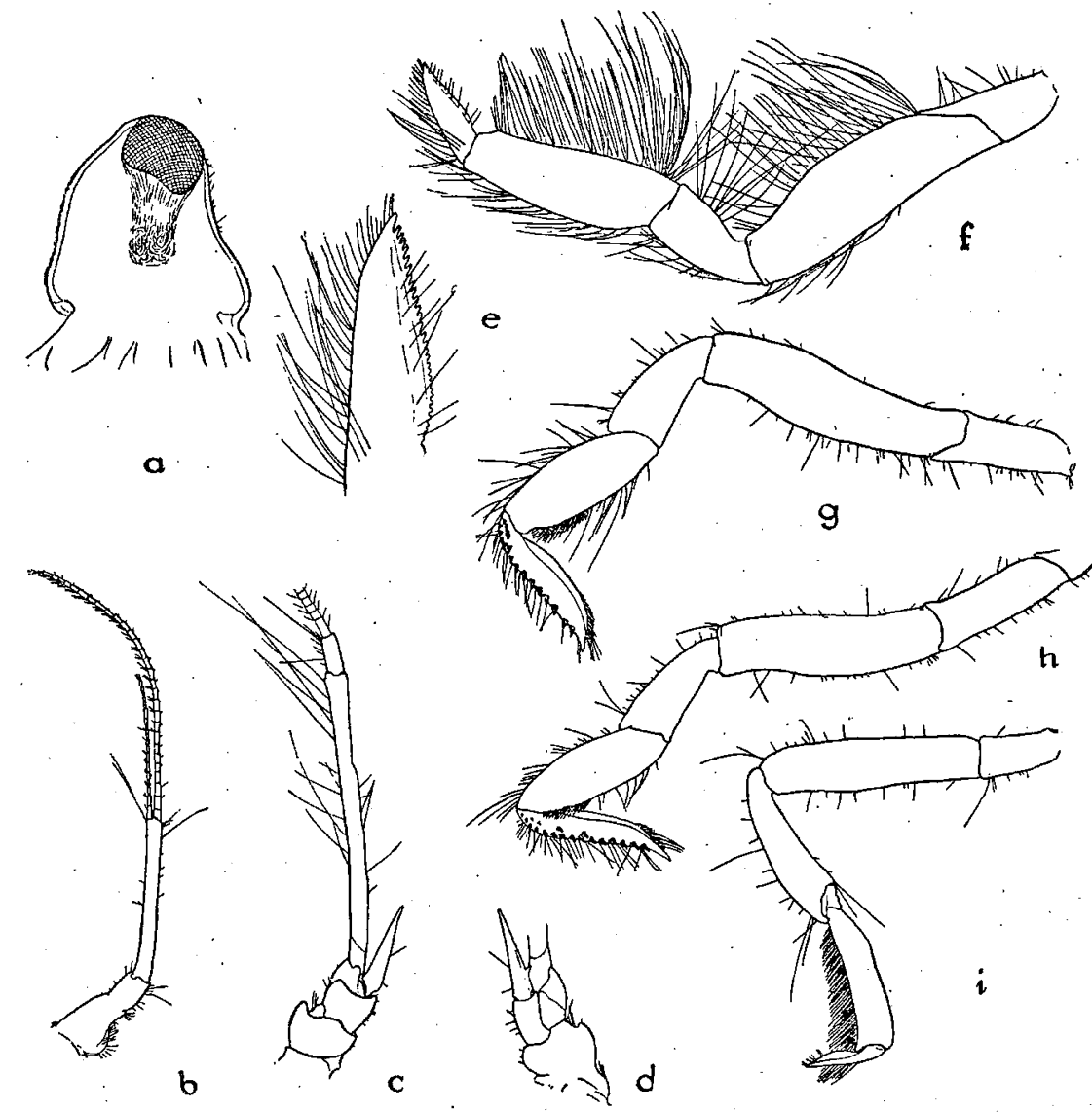

Fig. 7. - Axianassa intermedia new species. $a$. Eye stalk of right side. $b$. Antennule of left viui, varer aspect. $c$. Antennal peduncle of left side, outer aspect. $d$. Antennal peduncle efian aspect. $e$. Dactyl of second left leg, greatly enlarged. $f$., $g ., h$., $i$. Second to fifth legs of left side as viewed from above, in more or less natural position. of movable one crossing within tip of immovable when closed, movable finger with a row of subequal, small teeth on inner margin, teeth on fixed finger more irregular, somewhat larger and sharper; movable fingers of both hands longitudinally ridged, on either face, with line of hairs in the sulci above and below the median lateral ridges; carpus, merus and ischium of smaller hand much as in larger, carpus without teeth on outer hinder margin, and merus with fewer teeth on its inferior border; the large hand has an inconspicuous granulated carina marking the upper margin and a narrow granulated band, rather area marking the lower margin, smaller hand with a faint longitudinal carina above, none below.

Second legs simple, stoutest of the last four pairs; third and fourth pairs of legs similar though simple, unlike the first pair; fifth pair the weakest and differing from the others, the peculiar twisted flattened

dactyl, in closing brings its base against a tubercle-like production of the infero-distal angle of the propodus, in a way making this appendage imperfectly subchelate; when flexed the dactyl is at right angles to the longitudinal axis of the propodus; beneath, the propodus carries a thick fringe of hair, elsewhere the leg has but a few scattered hairs; dactyls of third and fourth legs when flexed make an angle of nearly $45^{\circ}$ with the propodus, the lower end of its inner side resting against a brush of thickly set, short hair on the distal third of the inferior margin of the preceding joint; on the upper, outer margin of these twisted and peculiarly flattened dactyls, there is a row of conspicuous dark corneous spines, proximally for the first three or four spines the row is double, and occasionally farther along to the extent of one or two other spines; dactyl of second leg more normal than others, not twisted, a longitudinal row of minute pectinations forming its inferior margin.

Epimera of abdominal somites virtually wanting on first somite, there is merely the line of demarcation between the ventral and lateral surfaces of the abdomen; on the second somite the epimera 
are barely suggested, near the postero-lateral angle just above the attachment of the pleopods; the epimera show to a slightly greater degree along the posterior two thirds of the third and fourth, and evident though poorly developed on the fifth and sixth somites. Tail fan well developed, telson and inner branches of the uropods subequal, or the inner branches may be slightly longer than the telson, outer branches a little shorter and broader than the inner, no transverse suture line, or joint on any of the elements composing the tail fan; telson truncate, triangular, about one twelfth longer than broad at its widest point in the figured male, to as broad as long in the largest female specimen; tail fan like rest of body covered, and fringed with short, scattered though rather evenly disposed hairs.

\section{Family Callianasside.}

Callianidea laevicauda Gill.

Callianidea laevicauda Gill, Proc. Acad. Nat. Sci. Phila., vol. 11, 1859, p. 167; RathBun, Bull. U. S. Fish Comm., vol. 20. pt. 2, 1900 (1901), p. 94.

Caracas Bay: under stones at the shore, 3. V. 20, $10^{7} 1$ \%

Family PAGURIDÆ.

Paguristes grayi Benedict.

Paguristes grayi Benedict, Bull. U. S. Fish Comm., vol. 20, pt. 2, 1900 (1901), p. 146, pl. 5, figs. 1, 1a. Spanish Water: no date, $1 \delta^{7}$, dried, broken.

Dimensions. - Carapace about $31 \mathrm{~mm}$. long over all, anterior portion about $18.5 \mathrm{~mm}$. long.

Remarks. - In general this species much resembles $P$. puncticeps Benedict (op. cit., p. 144, pl. 4, fig. 4). Unfortunately the lateral spines on the rostrum do not appear to be the rule, rather the exception. In the specimen before us, there is only the terminal spine on the rostral projection. BENEDICT, himself, found no spines on one of the three specimens upon which his description is based, while I have seen still another specimen of this species from Antigua which also is without lateral rostral spines. Aside from other differences, the strong spines on the lateral margins of the carapace will serve to distinguish $P$. grayi from puncticeps; in our specimen both before and behind the cervical groove, there are a number of stout spines, which only in part are feebly indicated in $P$. puncticeps; there is quite a group of long sharp spines behind the cervical groove and several slightly shorter, but stronger spines just before it. The hands in $P$. puncticeps are rather more armed with spiny-tipped granules than spines and have their surfaces obscured by their covering of long hair; in P. grayi the hands are but sparsely short bristled, not to the extent of obscuring the strong spines.

Clibanarius antillensis Stimpson.

Clibanarius antillensis StimpSon, Ann. Lyc. Nat. Hist. N. Y., vol. 7, 1859 (1862), p. 85 (39); RATHBUN, Proc. Wash. Acad. Sci., vol. 2, 1900, p. 144; BenEDict, Bull. U. S. Fish Comm., vol. 20, pt. 2, 1900 (1901), p. 142, pl. 6, fig. 1 .

Caracas Bay: between branches of Porites furcata, 2. IV. 20, 1 specimen.

Boca Labadera: 12. V. 20, 21 specimens.

West Punt: 19. V.20, 6 specimens.

Remarks. - As all of these specimens are quite small and their color markings have completely faded out, they are somewhat doubtfully assigned to this species. Color markings have always been of considerable importance in the recognition of species in this genus, and seem to be the only trustworthy character distinguishing $C$. antillensis from the more northerly ranging $C$. tricolor (Gibbes) (cf., BENEDict, op. cit., p. 142, pl. 6, fig. 2).

\section{Calcinus tibicen (Herbst).}

Cancer tibicen HeRBST, Naturg. d. Krabben u. Krebse, vol. 2, 1791, p. 25, pl. 23, fig. 7.

Calcinus sulcatus VerRiLL, Trans. Conn. Acad., vol. 13, 1908, p. 439, text figs. 56, 57, pl. 28, fig. 7; RATHBun, Proc. Wash. Acad. Sci., vol. 2, 1900, p. 144; Benedict, Bull. U. S. Fish Comm., vol. 20, pt. 2, 1900 (1901), p. 141, pl. 5, figs. 3, 3a.

Calcinus tibicen RATHBUN, Rapport betreffende een voorloopig onderzoek naar den toestand van de Visscherii 
en de Industrie van Zeeproducten in de Kolonie Curaçao, uitgebracht door Prof. Dr. J. BoEkE, pt. 2, 1920 , p. 329 [13].

Spanish Port: 16.IV. 20, $1 \sigma^{7}$.

Caracas Bay: under stones near shore, 3. V. 20, 1 \%; no date, 5 specimens.

Petrochirus bahamensis (Herbst).

Cancer bahamensis HeRBST, Naturg. d. Krabben u. Krebse, vol. 2, 1791, p. 30.

Petrochirus bahamensis RATHBUn, Ann. Inst. Jamaica, vol. 1, no. 1, 1897, p. 42; Benedict, Bull. U. S. Fish Comm., vol. 20, pt. 2, 1900 (1901), p. 140.

Caracas Bay: 28. IV.20, 1 q.

Pagurus marshi Benedict.

Pagurus marshi Benedict, Bull. U. S. Fish Comm., vol. 20, pt. 2, 1900 (1901), p. 139, 3 text figs.

Spanish Port: 10. IV. 20, $1 \sigma^{\top}$.

Caracas Bay: from stone at the shore, 30.IV.20, 4 specimens; without date, $30^{7}$.

Family COENOBITID

Coenobita clypeatus (Herbst).

Cancer clypeatus HERBST, Naturg. d. Krabben u. Krebse, vol. 2, 1791, p. 22, pl. 23, fig. 2A \& B.

Coenobita diogenes RATHBUn, Ann. Inst. Jamaica, vol. 1, no. 1, 1897, p. 42; BENEdict (spelled Cenobita),

Bull. U. S. Fish Comm., vol. 20, pt. 2, 1900 (1901), p. 139.

Coenobita clypeatus RATHBUN, Rapport betreffende een voorloopig onderzoek naar den toestand van de Visscherij en de Industrie van Zeeproducten in de Kolonie Curaçao, uitgebracht door Prof. Dr. J. BoEkE, pt. 2, 1920, p. 329 [13].

Caracas Bay: on the stairs of the quarantine station, 6. IV. 20, $1 \sigma^{\nearrow} 3$ \% ; on land, 7. IV. 20, $2 \delta^{\nearrow} 1$ ㅇ.

Plantation Jan Tiel: 7. V. 20, $1 \delta^{7}$.

Family HiPPIDE.

Hippa cubensis (Saussure).

Remipes cubensis SAUSSURE, Rev. et Mag. Zool., ser. 2, vol. 9, 1857, p. 503.

Hippa cubensis BENEDICT, Bull. U. S. Fish Comm., vol. 20, pt. 2, 1900 (1901), p. 139; Verrill, Trans. Conn. Acad., vol. 13, 1908, p. 436, text figs. 53, 54; RATHBUN, Rapport betreffende een voorloopig onderzoek naar den toestand van de Visscherij en de Industrie van Zeeproducten in de Kolonie Curaçao, uitgebracht door Prof. Dr. J. BoEkE, pt. 2, 1920, p. 330 (14).

Caracas Bay: under the sand at the shore, 7.IV.20, $2 \sigma^{7} ; 13$. IV.20, $12 \sigma^{7} 3$ o (2 ovigerous); 14. IV. 20 , $3 \sigma^{7} 4$ 우 ovigerous.

\section{Order STOMATOPODA.}

\section{Gonodactylus oerstedii Hansen.}

Gonodactylus oerstedii HANSEN, Isopoden, Cumaceen und Stomatopoden, Ergebnisse der Plankton-Expedition der Humboldt-Stiftung, Bd. 2, G. c. 1895, p. 65; BIGelow, Bull. U. S. Fish Comm., vol. 20, pt. 2, 1900 (1901), p. 152, text figs. 1, 2; RATHBUN, Rapport betreffende een voorloopig onderzoek naar den toestand van de Visscherij en de Industrie van Zeeproducten in de Kolonie Curaçao, uitgebracht door Prof. Dr. J. BOEKE, pt. 2, 1920, p. 348 [32].

Spanish Water: from Porites furcata, 13. IV.20, 1 \% ; 5. V. 20, $1 \sigma^{7} 1$ ㅇ.

Spanish Port: 17. IV.20, $1 \sigma^{\pi} 1$ \%; 6. V.20, $1 \sigma^{\nearrow} 1$ \%.

Spanish Bay: between stones in the surf, 11. V.20, $1 \sigma^{\nearrow}$.

Caracas Bay: 10. IV. 20, $1 \sigma^{\top}$; 19. IV. 20, $2 \sigma^{\top} 1$ \%; 1. V.20, $1 \sigma^{7}$; under stones at the shore, 3 . V. 20,2 juvenile; 6. V. 20, 2 우 ; 25. V.20, 1 juvenile.

Gonodactylus oerstedii var. curaçaoensis new variety. (P1. VIII, fig. 6).

Ty pe-1 o cality. - Caracas Bay: from Porites furcata, 5. V. 20, 2 q.

Dimensions. - Larger specimen, length about $49 \mathrm{~mm}$., carapace and rostrum 14, rostrum 3.25 , telson over all 8.5 , greatest width of telson $7.5 \mathrm{~mm}$.; smaller specimen, length about $42.5 \mathrm{~mm}$., carapace and rostrum 11.75, rostrum 3, telson over all 7, greatest width of telson $6.25 \mathrm{~mm}$.

Description and remarks. - These specimens are so nearly like $G$. oerstedii in nearly all particulars that it does not seem justifiably possible to separate them as a distinct species. 
The juvenile, and many of the younger smaller specimens of $G$. oerstedii often have the rounded longitudinal prominences of the telson furnished with, usually but indications of, a small posterior spine, and occasionally they are somewhat, more or less, carinated. Our varietal form seems to be one in which the characters of the immature telson have become accentuated in the direction of sharpness of spines and carination rather than the reverse as seems typical with $G$. oerstedii. The usual rounded prominences are distinctly and quite-sharply carinated, and posteriorly produced into well-formed spines; the telson is longer than wide, in the typical species it is usually as wide as or wider than long over all, and the sinus between the posterior median teeth appears deeper and narrower. The rostral spine is more slender and the rostral plate seems to be somewhat more excavate, or concave either side of it than in the typical form; too, the swollen basal portion of the dactyl of the raptorial limb seems to be relatively more inflated, almost subglobular, than in the typical species.

It does not seem that these characters are sufficiently distinctive to permit the separation of this varietal form from some specimens of $G$. oerstedii of about two $\mathrm{cm}$. long or less, no matter how different larger specimens may appear, hence the restriction of our specimens to a varietal status.

\section{Pseudosquilla ciliata (Fabricius).}

Squilla ciliata FABRIcIUS, Ent. Syst., vol. 2, 1793, p. 512.

Pseudosquilla ciliata Braelow, Bull. U. S. Fish Comm., vol. 20, pt. 2, 1900 (1901), p. 154, text figs. 3, 4; RATHBUN, Rapport betreffende een voorloopig onderzoek naar den toestand van de Visscherij en de Industrie van Zeeproducten in de Kolonie Curaçao, uitgebracht door Prof. Dr. J. BoEKE, pt. 2, 1920, p. 347 [31].

Spanish Water: 3.IV.20, 1 \%; 23. IV. 20, 1 ․

Spanish Port: 10. IV. 20, 10 .

Caracas Bay: 19. IV. 20, 1 juvenile; 1. V. 20, 1 juvenile.

\section{Pseudosquilla monodactyla (Milne Edwards).}

Squilla monodactyla Milne Edwards, Bull. Soc. Philom. Paris, ser. 7, vol. 2, 1878, p. 232.

Pseudosquilla monodactyla MIERS, Ann. Mag. Nat. Hist., ser. 5, vol. 5, 1880, p. 110, pl. 3, figs. 1, 2; RATHBUN, Rapport betreffende een voorloopig onderzoek naar den toestand van de Visscherij en de Industrie van Zeeproducten in de Kolonie Curaçao, uitgebracht door Prof. Dr. J: BoEKE, pt. 2, 1920, p. 348 [32].

Caracas Bay: 19. IV. 20, 1 juvenile.

Chloridella alba (Bigelow).

Squilla alba Bigelow, Johns Hopkins Univ. Circ., no. 106, 1893, p. 103; Proc. U. S. Nat. Mus., vol. 17, 1894, p. 539, p1. 22.

Spanish Water: 26. IV.20, 1 ㅇ.

Spanish Port: sieved out of the sand, 17.IV.20, 1 \%. 


\section{LIST OF ILLUSTRATIONS.}

Pisosoma curaçaoensis new species.

Fig. 1, dorsal view of $\sigma^{\lambda}$, dorsal view of hands, without brush of hair.

Fig. 2, o, ovigerous, dorsal view, both hands with brush of hair.

Fig. 3, dorsal view of $\sigma^{7}$, with brush of hair on smaller hand.

Axianassa intermedia new species.

Fig. 4, $\sigma^{7}$, outer face of either hand.

Fig. 5, $\sigma^{\lambda}$, dorsal view of anterior end.

Gonodactylus oerstedii var. curaçaoensis new variety.

Fig. 6,9 , dorsal view of posterior end of abdomen and tail fan.

Petrolisthes van der horsti new species.

Fig. 7, $\sigma^{7}$, holotype, dorsal view.

Petrolisthes nodosus Streets.

Fig. 8 , $q$ ovigerous, dorsal view. 


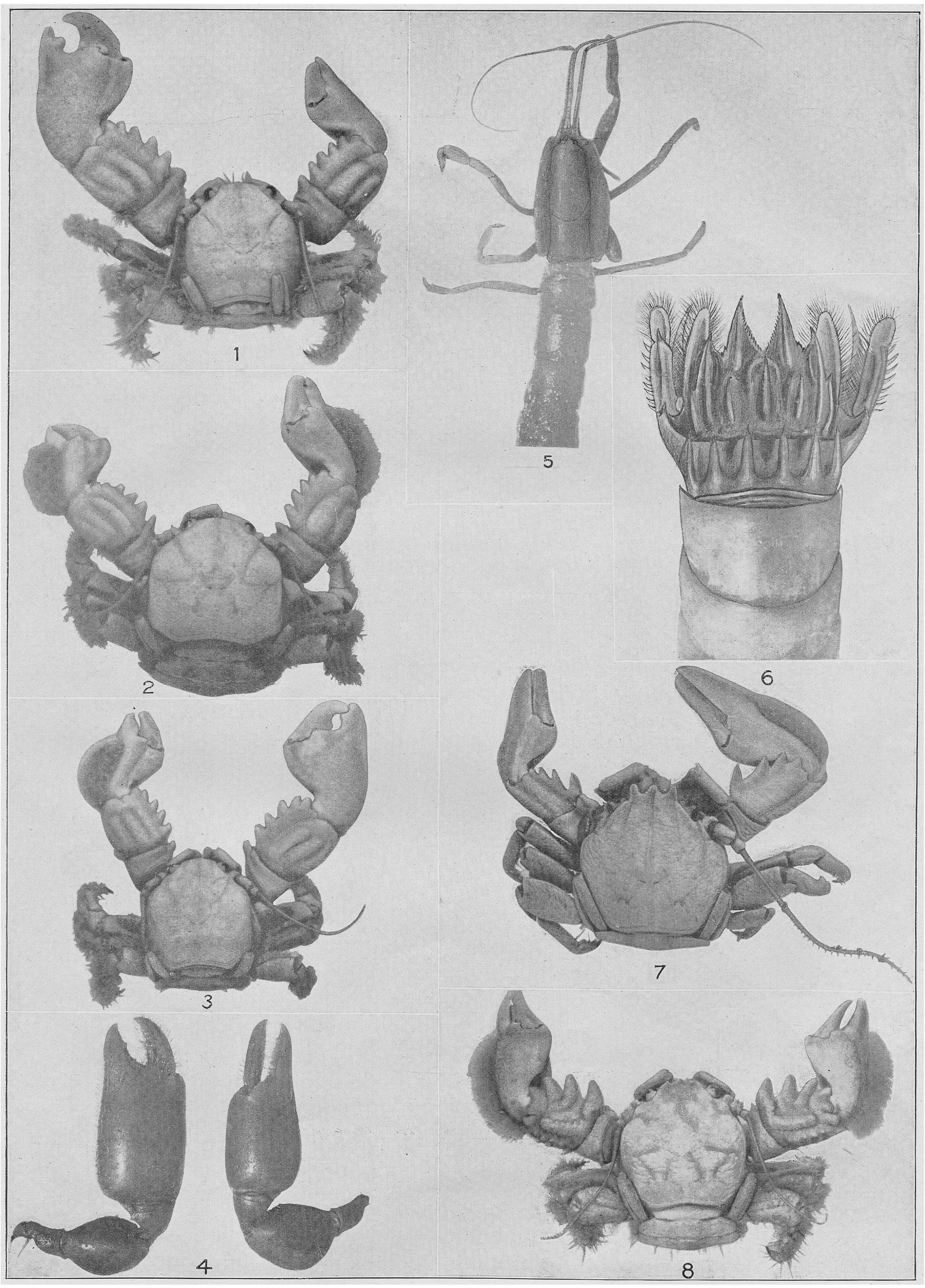

